\title{
Environmental and biological controls on seasonal patterns of isoprene above a rain forest in central Amazonia
}

\author{
Authors: Dandan Wei, Jose D. Fuentes, , Tobias Gerken, \\ Marcelo Chamecki, Amy M. Trowbridge, Paul C. Stoy, \\ Gabriel G. Katul, Gilberto Fisch, Otávio Acevedo, Antonio \\ Manzi, Celso von Randow, Rosa Maria Nascimento dos \\ Santos
}

NOTICE: this is the author's version of a work that was accepted for publication in Agricultural \& Forest Meteorology. Changes resulting from the publishing process, such as peer review, editing, corrections, structural formatting, and other quality control mechanisms may not be reflected in this document. Changes may have been made to this work since it was submitted for publication. A definitive version was subsequently published in Agricultural \& Forest Meteorology, Volume 256-257, (June 15, 2018), DOI\#10.1016/j.agrformet.2018.03.024

Wei, Dandan, Jose D. Fuentes, Tobias Gerken, Marcelo Chamecki, Amy M. Trowbridge, Paul C. Stoy, Gabriel G. Katul, Gilberto Fisch, Otávio Acevedo, Antonio Manzi, Celso von Randow, and Rosa Maria Nascimento dos Santos. "Environmental and biological controls on seasonal patterns of isoprene above a rain forest in central Amazonia." Agricultural \& Forest Meteorology 256-257 (June 2018): 391-406. DOI:10.1016/j.agrformet.2018.03.024. 


\title{
Environmental and biological controls on seasonal patterns of isoprene above a rain forest in central Amazonia
}

\author{
Dandan Wei $^{\mathrm{a}}$, Jose D. Fuentes ${ }^{\mathrm{a}, *}$, Tobias Gerken ${ }^{\mathrm{a}, \mathrm{c}}$, Marcelo Chamecki ${ }^{\mathrm{b}}$, Amy M. Trowbridge , $^{\mathrm{c}}$ \\ Paul C. Stoy ${ }^{\mathrm{c}}$, Gabriel G. Katul ${ }^{\mathrm{d}}$, Gilberto Fisch ${ }^{\mathrm{e}}$, Otávio Acevedo ${ }^{\mathrm{f}}$, Antonio Manzi ${ }^{\mathrm{g}}$, \\ Celso von Randow ${ }^{\mathrm{h}}$, Rosa Maria Nascimento dos Santos ${ }^{\mathrm{i}}$ \\ a Department of Meteorology and Atmospheric Science, The Pennsylvania State University, University Park, PA, USA \\ ${ }^{\mathrm{b}}$ Department of Atmospheric and Oceanic Sciences, University of California, Los Angeles, Los Angeles, CA, USA \\ ${ }^{\mathrm{c}}$ Department of Land Resources and Environmental Sciences, Montana State University, Bozeman, MT, USA \\ ${ }^{\mathrm{d}}$ Nicholas School of the Environment, Duke University, Durham, NC, USA \\ e Aeronautical and Space Institute, Department of Science and Aerospace Technology, São Paulo, Brazil \\ ${ }^{\mathrm{f}}$ Universidade Federal de Santa Maria, Santa Maria, Rio Grande do Sul, Brazil \\ ${ }^{g}$ Centro de Previsão de Tempo e Estudos Climáticos (CPTEC), Instituto Nacional de Pesquisas Espaciais (INPE), Cachoeira Paulista, São Paulo, Brazil \\ ${ }^{\mathrm{h}}$ National Institute for Space Research (INPE), São José dos Campos, São Paulo, Brazil \\ ${ }^{\mathrm{i}}$ Universidade do Estado do Amazonas, Manaus, Brazil
}

\begin{abstract}
A B S T R A C T
The Amazon rain forest is a major global isoprene source, but little is known about its seasonal ambient concentration patterns. To investigate the environmental and phenological controls over isoprene seasonality, we measured isoprene mixing ratios, concurrent meteorological data, and leaf area indices from April 2014 to January 2015 above a rain forest in the central Amazon, Brazil. Daytime median isoprene mixing ratios varied throughout the year by a factor of two. The isoprene seasonal pattern was not solely driven by sunlight and temperature. Leaf age and quantity also contributed to the seasonal variations of isoprene concentrations, suggesting leaf phenology was a crucial variable needed to correctly estimate isoprene emissions. A zero-dimensional model incorporating the estimated emissions, atmospheric boundary layer dynamics, and air chemistry was used to assess the contributions of each process on the variability of isoprene. Surface deposition was an important sink mechanism and accounted for $78 \%$ of the nighttime loss of isoprene. Also, chemical reactions destroyed isoprene and during 6:00 to $18: 00 \mathrm{~h}$ local time $56,77,69$, and $69 \%$ of the emitted isoprene was chemically consumed in June, September, December, and January, respectively. Entrainment fluxes from the residual layer contributed $34 \%$ to the early-morning above-canopy isoprene mixing ratios. Sensitivity analysis showed that hydroxyl radical (HO) recycling and segregation of isoprene-HO played relatively lesser roles (up to $16 \%$ ) in regulating ambient isoprene levels. Nitric oxide (NO) levels dominated isoprene chemical reaction pathways associated with consumption and production of $\mathrm{HO}$ under low-NO and high volatile organic compound (VOC) conditions. While surface deposition and oxidative processes altered isoprene levels, the relative importance of these factors varied seasonally with leaf phenology playing a more important role.
\end{abstract}

\section{Introduction}

Among the biogenic volatile organic compounds, isoprene $\left(\mathrm{C}_{5} \mathrm{H}_{8}, 2\right.$ methyl-1,3-butadiene) is the most abundantly emitted from the foliage of woody plant species. Its ecological function is still unclear, but current and prevailing consensus indicates that isoprene may act to increase the thermal protection of photosynthesis at high temperature ( $>313 \mathrm{~K}$ ) by either stabilizing the thylakoid membranes (Sharkey and Yeh, 2001) or quenching reactive oxygen species (Loreto and Velikova,
2001). The biosynthesis of isoprene is associated with the carboxylation process in the leaf chloroplast (Sharkey et al., 2008), and foliage temperature and intercepted photosynthetically active radiation (PAR) regulate emissions via stomata (Fall and Monson, 1992). Foliage temperature activates the enzyme responsible for isoprene biosynthesis (Monson and Fall, 1989) whereas PAR provides the energy to acquire the necessary carbon substrate to produce isoprene (Sharkey et al., 1991). Isoprene emissions occur only during the daytime and vary greatly with foliage phenology. Laboratory (Grinspoon et al., 1991) and 


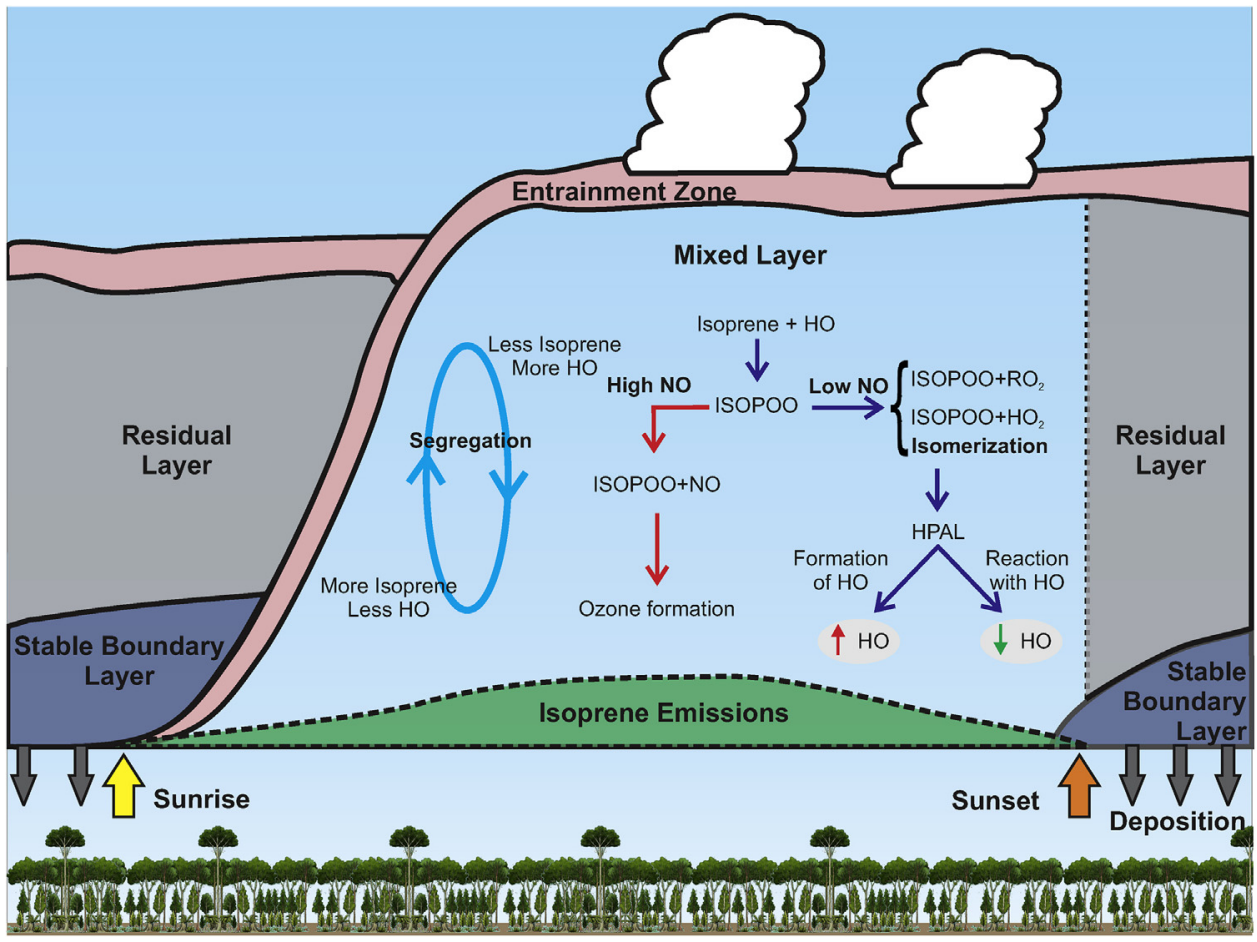

Fig. 1. Temporal variations of isoprene over the rain forest depend on emission, surface deposition, chemical transformation, and transport in (entrainment) and out (detrainment) of the atmospheric boundary layer. Each process differently contributes to ambient isoprene mixing ratios over the course of the day. After being emitted during the daytime, turbulence redistributes isoprene throughout the boundary layer while reactions with hydroxyl radicals (HO) decrease its concentration. Subsequent reaction pathways depend on nitric oxide (NO) levels. Under high NO conditions, ozone is generated while under low NO conditions notable amounts of $\mathrm{HO}$ can be recycled through isomerization of isoprene peroxy radicals (ISOPOO). Incomplete turbulent mixing slows down the reactions of isoprene with HO, and segregation of isoprene-HO can occur. Air entrainment from the free atmosphere into the mixed layer and deep boundary layer depths support rapid isoprene dilution, primarily during the morning when accelerated development of the convective boundary layer occurs. All these processes control the temporal patterns of isoprene mixing ratios above the rain forest. Figure modeled after Stull (1988). field (Monson et al., 1994; Fuentes and Wang, 1999) studies demonstrate that leaves older than 2-4 weeks emit isoprene but younger leaves do not, even though they are competent to assimilate carbon dioxide $\left(\mathrm{CO}_{2}\right)$ (Fuentes et al., 1999; Wilkinson et al., 2009).

In this study we aim to (i) investigate the degree of seasonality in isoprene concentration using field experiments and (ii) identify the main processes explaining such seasonality via a zero-dimensional model that includes sources and sinks of isoprene as well as atmospheric boundary layer dynamics. Additional verifications on modeled links between ambient isoprene and its sources/sinks were conducted using diurnal concentration variations across different seasons. Once released from foliage, isoprene molecules can undergo surface deposition onto the plant canopy, can be oxidized, and can be transported into and out of the atmospheric boundary layer (ABL) (Fig. 1). Isoprene oxidation occurs via reactions with hydroxyl radical $(\mathrm{HO})$, ozone $\left(\mathrm{O}_{3}\right)$, and nitrate radical $\left(\mathrm{NO}_{3}\right)$. Because of chemical reactions, isoprene molecules tend to reside in the atmosphere for just a few hours (Table 1).

Isoprene has a substantial impact on the chemistry of the atmosphere in the boundary layer overlying forested environments. The Amazon rain forest mostly experiences low levels of nitrogen oxides $\left(\mathrm{NO}_{x}=\mathrm{NO}+\mathrm{NO}_{2}\right)$. Occasionally, high $\mathrm{NO}_{x}$ levels are observed due to biomass burning (Gerken et al., 2016). Under higher $\mathrm{NO}_{x}$ conditions, isoprene oxidation processes contribute to the formation of $\mathrm{O}_{3}$ (Kuhn et al., 2007). In addition, products of isoprene photooxidation are

Table 1

Isoprene chemical lifetimes with respect to assumed mixing ratios (in parts per billion on a volume basis, ppbv) of hydroxyl radical, ozone, and nitrate radical.

\begin{tabular}{llll}
\hline Oxidant & $\begin{array}{l}\text { Rate coefficient } \\
\left(\mathrm{cm}^{3} \text { molecule }^{-1} \mathrm{~s}^{-1}\right)\end{array}$ & $\begin{array}{l}\text { Mixing ratio } \\
(\mathrm{ppbv})\end{array}$ & $\begin{array}{l}\text { Chemical } \\
\text { lifetime (h) }\end{array}$ \\
\hline $\begin{array}{c}\text { Hydroxyl } \\
\text { radical }\end{array}$ & $1.0 \times 10^{-10}$ & $1.0 \times 10^{-4}$ & 1 \\
$\begin{array}{c}\text { Ozone } \\
\text { Nitrate } \\
\text { radical }\end{array}$ & $\begin{array}{l}1.28 \times 10^{-17} \\
6.86 \times 10^{-13}\end{array}$ & 20.0 & 44 \\
& & $5.0 \times 10^{-3}$ & 3 \\
\hline
\end{tabular}

${ }^{a}$ Reaction rate coefficients are from Atkinson (1997) at temperature of $298 \mathrm{~K}$. important precursors to secondary organic aerosols (SOA), particularly in the rain forest where isoprene is abundantly produced year round (Claeys et al., 2004; Paulot et al., 2009b; Surratt et al., 2009). Because SOAs can grow sufficiently large to activate and become cloud condensation nuclei (CCN) and scatter and absorb solar irradiance, they play critical roles in weather and climate (Pöschl et al., 2010). Also, theoretical and experimental studies (Taraborrelli et al., 2012; Fuchs et al., 2013) indicate that the photooxidation of isoprene may contribute to appreciable amounts of $\mathrm{HO}$ recycling. In environments such as the rain forest, isoprene plays a central role in sustaining the oxidation capacity of the lower atmosphere by adjusting HO levels (Lelieveld et al., 2008; Nölscher et al., 2016). Hence, it is necessary to estimate seasonal emission rates, ambient levels, and oxidation rates of isoprene in the tropical rain forest to establish regional SOA and HO budgets, and to develop an improved understanding of the role of rain forests in the Earth system.

Tropical rain forests experience year-round high temperature and PAR levels and may thus be assumed to support minor seasonality in isoprene emissions (Levis et al., 2003). However, strong seasonality in ambient isoprene levels is observed over the Amazon rain forest (Kesselmeier, 2002; Kuhn et al., 2004). Studies on tropical tree species show mature leaves exhibit higher isoprene emissions than new leaves ( 2 versus $30-40 \mathrm{nmol} \mathrm{m}^{-2} \mathrm{~s}^{-1}$; Figure $4 \mathrm{~b}$ in Jardine et al., 2016). Also, remote sensing studies (Barkley et al., 2008) in the Amazon basin demonstrate that variations in leaf area and enhanced vegetation indices (EVI) before the dry season are consistent with observed decreases in the slant atmospheric columns of formaldehyde (HCHO, Palmer et al., 2007), which is a high-yield product of isoprene oxidation and is assumed as a proxy for isoprene emissions (Palmer et al., 2006). Such results suggest large-scale reductions in isoprene biosynthesis due to new leaf growth prior to the dry season. While co-located seasonal isoprene and phenology measurements are not available for the Amazon rain forest, close links exist between phenology and photosynthesis (Wu et al., 2016), which would be consistent with the observed seasonality in isoprene emissions. Previous ecosystem-level studies in the tropical rain forest (Rinne et al., 2002; Greenberg et al., 2004; Karl et al., 2004; Kuhn et al., 2007; Rizzo et al., 2010; Jardine et al., 2012) were performed during brief periods and confirmed 
seasonal variations in isoprene emission activity deduced from forest canopy flux densities. Nonetheless, long-term studies are still needed in the tropics to constraint budgets of biogenic hydrocarbons and resulting sources and sinks of atmospheric oxidants and SOAs.

\section{Research methods}

\subsection{Study site}

The field campaign took place at the Cueiras Biological Reserve (N $2^{\circ} 36.11^{\prime}, \mathrm{E} 60^{\circ} 12.56^{\prime}$ ), in the central Amazon basin, Brazil from April 2014 to January 2015 as part of the GoAmazon 2014/5 project (Fuentes et al., 2016). The study site (called the K34 tower at ZF2, and designated as T0k, located about $120 \mathrm{~km}$ from T3 site during GoAmazon 2014/5 (Martin et al., 2016)) is approximately $60 \mathrm{~km}$ north-northwest of the city of Manaus, Amazonas, Brazil and is part of the Large-Biosphere-Atmosphere (LBA) experiment (Araújo et al., 2002). The reserve covers approximately $230 \mathrm{~km}^{2}$ of largely undisturbed lowland evergreen rain forest with a canopy height of about $35 \mathrm{~m}$ (Luizao, 1995) surrounding a 50-m tower that served as a platform to mount meteorological instruments and air samplers. The leaf area index (LAI) is estimated to be $5-6 \mathrm{~m}^{2} \mathrm{~m}^{-2}$ (McWilliam et al., 1993; Marques Filho et al., 2005), with maximum LAI values reaching $7.3 \mathrm{~m}^{2} \mathrm{~m}^{-2}$ (Tóta et al., 2012). Myneni et al. (2007) reported LAI seasonal variations reaching $1 \mathrm{~m}^{2} \mathrm{~m}^{-2}$ in the Amazon basin. Due to prevailing easterly wind, the air masses arriving at the site mostly come from vast expanses of undisturbed rain forest. However, the site occasionally experiences the influences of biomass burning during the dry season when high NO ( $>2$ ppbv) and $\mathrm{O}_{3}$ ( $>50$ ppbv) levels can be recorded (Artaxo et al., 2013; Gerken et al., 2016).

\subsection{Trace gas and meteorological measurements}

Mixing ratios of trace gases were measured at the fixed level of $40 \mathrm{~m}$ above the ground surface. Ozone (model 49i, Thermo Fisher Scientific Inc., Waltham, MA) and nitrogen oxides ( $\mathrm{NO}$ and $\mathrm{NO}_{2}$, model 48i, Thermo Fisher Scientific Inc.) were measured at the frequency of $1 \mathrm{~Hz}$ and reduced to generate half hourly averages. A Proton Transfer Reaction-Mass Spectrometer (PTR-MS, Ionicon Analytik Ges.m.b.H., Innsbruck, Austria) measured ambient levels of volatile organic compounds (VOCs), including isoprene and methanol $\left(\mathrm{CH}_{3} \mathrm{OH}\right)$. The PTRMS was purposely configured to make measurements in slow-response $(1 \mathrm{~Hz})$ mode to optimize the reliable measurements of multiple gases. Therefore, eddy-covariance hydrocarbon fluxes did not exist for the field campaign. Pumps drew ambient air from the inlet at $40 \mathrm{~m}$ to a heated (to prevent condensation) manifold unit that was housed in an environmentally controlled hut, located $3 \mathrm{~m}$ away from the tower. The manifold unit had several outlet ports to allow the ambient air to pass through different gas analyzers. For isoprene measurements, the PTRMS monitored the mass (m) and charge number of ions ( $z$ ) ratio, $m / z$, of 69. The PTR-MS was calibrated before, during, and after the field studies. Commercial mixture gas standards in high-purity air (Apel-Riemer Environmental, Inc., Boulder, CO) contained 15 different compounds (including isoprene) at mixing ratios of $\sim 500 \mathrm{ppbv}$ and diluted the standard mixtures using zero air that was created at the site via a catalytic converter (Restek, Inc., Bellefonte, PA) and a series of mass flow controllers. After subtracting zero air from the measured counts per second, the average normalized counts per second (ncps), which were normalized by both $m / z 21$ and 37, were plotted against the gas mixing ratio at four different levels. The calibration factor (ncps/ppbv \pm uncertainty) was then applied to the field measurements after subtracting intermittent zeros in order to obtain final gas concentrations. Fuentes et al. (2016) and Freire et al. (2017) provide full details on air sampling procedures, and operation and calibration protocols of the gas analyzers. In this study, air chemistry data for June, September, December, and January (2015), incorporating both wet and dry seasons, are presented and discussed.

Meteorological and air turbulence measurements provided contextual information to understand seasonal variations of isoprene. Nine sonic anemometers (model CSAT3, Campbell Scientific Inc, Logan, UT), deployed at 7.0, 13.5, 18.4, 22.1, 24.5, 31.6, 34.9, 40.4, 48.2 $\mathrm{m}$ above the ground, recorded the three components of the wind speed $(u, v$, and $w$ ) and virtual temperature $\left(T_{V}\right)$ at the frequency of $20 \mathrm{~Hz}$ (Santos et al., 2016). Using the air turbulence data, the kinematic virtual heat flux $\left(\left(\overline{w^{\prime} \theta_{V}^{\prime}}\right)_{s}, \theta_{V}\right.$ is the virtual potential temperature derived from $\left.T_{V}\right)$ at $48.2 \mathrm{~m}$ above the ground were calculated to determine the depth $\left(z_{i}\right)$ of the ABL (see details in Section 2.3). A quantum sensor (model Li190, LiCor Biosciences, Lincoln, NE) recorded PAR, and a thermometer/ hygristor probe (model HMP-155, Väisälä, Vantaa, Finland) measured air temperature and relative humidity at $51.6 \mathrm{~m}$ and $32.0 \mathrm{~m}$ above the ground, respectively. Rain gauges (model RIMB500, McVan Instruments, Melbourne, Australia), deployed at a site located $3.1 \mathrm{~km}$ away from the flux tower, recorded rainfall amounts. Analyses also included rainfall data from the GoAmazon2014/5 T3 study site.

\subsection{Modeling isoprene temporal variability}

Isoprene mixing ratios in the $\mathrm{ABL}$ are governed by emissions, chemical reactions, surface deposition, and exchange processes between the ABL and the free atmosphere. In this study, a zero-dimensional model was employed to estimate the temporal evolution of isoprene in the mixed layer (ML), $\partial\langle\mathrm{ISOP}\rangle_{M L} / \partial t$, under the assumption of surface homogeneity and instantaneous atmospheric mixing of isoprene and its reactants (it is hereby assumed that the bottom of the ML starts at the top of the forest canopy). The validity of the mixing assumption will be evaluated by incorporating the segregation of species (see below). Under the stated assumptions, the isoprene budget is thus given by

$\frac{\partial\langle\mathrm{ISOP}\rangle_{\mathrm{ML}}}{\partial t}=\frac{E-F_{e}-D}{z_{i}}+f_{\text {Chem }}$.

$E$ denotes isoprene emission rates, $F_{e}$ represents the isoprene flux at the top of the ML caused by entrainment and detrainment, $D$ is the isoprene surface deposition rate, and $f_{\text {Chem }}$ is the destruction rate of isoprene due to gas-phase reactions. The effect of a growing convective boundary layer is included via the variable $z_{i}$.

Isoprene emission rates ( $E$ in Eq. (1)) are estimated following established algorithms (the MEGAN (Model of Emissions of Gases and Aerrosols from Nature) model) (Guenther et al., 2006, 2012), as shown in Eq. (2).

$E=[\epsilon][\gamma][\rho]$

$\epsilon$ is the basal isoprene emission rate $\left(\mathrm{mg} \mathrm{m}^{-2} \mathrm{~h}^{-1}\right)$ defined at the standardized conditions of PAR level of $1000 \mu \mathrm{mol}$ (photons) $\mathrm{m}^{-2} \mathrm{~s}^{-1}$ and leaf temperature of $300 \mathrm{~K}$. The magnitude of $\epsilon$ depends on plant types (Guenther et al., 2012). The $\gamma$ factor (i.e., a ratio) accounts for emission changes due to deviation from normalized conditions. The $\rho$ (normalized ratio) accounts for loss of isoprene within the forest canopy (in this study $\rho$ is assumed $=1$ ). The algorithm considers the main processes influencing isoprene emissions such as the light response $\left(\gamma_{P}\right)$ in acquiring the carbon substrate, temperature response based on enzymatic activity responsible for isoprene biosynthesis $\left(\gamma_{T}\right)$, leaf age $\left(\gamma_{A}\right)$, LAI, emission inhibition due to $\mathrm{CO}_{2}$ levels $\left(\gamma_{C}\right)$, and soil moisture $\left(\gamma_{S M}\right)$, as shown in Eq. (3) (Guenther et al., 2012).

$\gamma=C_{\mathrm{CE}} \mathrm{LAI} \gamma_{P} \gamma_{T} \gamma_{A} \gamma_{\mathrm{C}} \gamma_{\mathrm{SM}}$

$C_{C E}$ represents the type of canopy environment, and following previous studies (Guenther et al., 2006) the value of 0.57 is used. The $\mathrm{CO}_{2}$ response $\left(\gamma_{C}\right)$ was set to 1 . During the study period, for the volumetric soil moisture values $\left(0.28-0.48\right.$ in $\left.\mathrm{m}^{3} \mathrm{~m}^{-3}\right)$ recorded at the soil depths ranging from 10 to $75 \mathrm{~cm}$, the forest most likely did not experience water-related stress. In the rain forest, water storage occurs in deep soil columns. Therefore, plant roots can access moisture stored in the soil at 
depths reaching up to about $10 \mathrm{~m}$ (Bruno et al., 2006). Even during the dry season when near-surface soil dries, trees can access deep soil water and as a result exhibit little evidence of stress (Nepstad et al., 1994). Therefore, the soil moisture $\left(\gamma_{S M}\right)$ influences on emissions was set to 1 . The isoprene emission algorithm was executed with the measured PAR levels and air temperature. Due to the incomplete canopy surface temperature $\left(T_{s f c}\right)$ dataset, the air temperature $\left(T_{a}\right)$ was used to determine isoprene emissions. Analyses of the limited $T_{s f c}$ data for September showed that during 8:00 to 16:00 local hours the $T_{s f c}$ was $1.6 \pm 0.4^{\circ} \mathrm{C}$ greater than $T_{a}$ (for the other times, the canopy was cooler than the air). Small differences between $T_{a}$ and $T_{s f c}$ prevailed due to preponderance of cloudiness (which reduced the solar radiation loading on the foliage) and lack of soil moisture stress. For daytime conditions, the averaged temperature of forest crown canopies without soil moisture stress can be ordinarily within $3{ }^{\circ} \mathrm{C}$ (Fuentes et al., 1995; Gao et al., 2008), although individual sunlit leaves reach temperatures as much as $15^{\circ} \mathrm{C}$ above air temperature (Singsaas et al., 1999). To estimate the uncertainties associated with the differences between $T_{a}$ and $T_{s f c}$, several simulations were performed with temperature values that were $0.5,1.0,2.0$, and $3.0^{\circ} \mathrm{C}$ higher than air temperature. Results indicated that these higher temperature values $\left(0.5,1.0,2.0\right.$, and $3.0^{\circ} \mathrm{C}$ higher) resulted in $1 \%, 3 \%, 12 \%$ and $21 \%$ overestimates in isoprene emission rates, respectively.

The LAI data are obtained from the Moderate Resolution Imaging Spectroradiometer (MODIS) onboard the National Aeronautics and Space Administration's (NASA's) Terra satellite. Datasets are provided at the $1 \mathrm{~km} \times 1 \mathrm{~km}$ resolution. The best-quality daily retrievals are averaged over an 8-day period. The MODIS data have been reprocessed several times with the latest available algorithms, calibration, and geolocation information. In this study, the collection-5 MODIS Terra LAI products are used (Yang et al., 2006). The 8-day LAI products were further processed into monthly averages in the study. The MODIS-derived LAI can have uncertainties reaching $20 \%$, mostly due to the overestimates of absorbed PAR (Fensholt et al., 2004). The leaf age emission activity factor $\gamma_{A}$ is estimated as:

$\gamma_{A}=F_{\text {new }} A_{\text {new }}+F_{\text {mat }} A_{\text {mat }}+F_{\text {old }} A_{\text {old }}$

where $A_{\text {new }}(=0.05), A_{\text {mat }}(=1)$, and $A_{\text {old }}(=0.9)$ are empirical coefficients that describe the relative emission rates for new, mature, and old leaves, respectively (Guenther et al., 2012). $F_{\text {new }}, F_{\text {mat }}$, and $F_{\text {old }}$ represent leaf age fractions estimated by Wu et al. (2016). Estimates of leaf demographic dynamics (i.e., $F_{\text {new }}, F_{\text {mat }}$, and $F_{\text {old }}$ ) were constrained by three sets of observations, including the total LAI, the litter fall LAI, and the new leaf production (Wu et al., 2016). Guenther et al. (2006, 2012) provide additional details about the isoprene emission algorithm.

Dry deposition is an efficient sink for gaseous chemical species in tropical forests (Fan et al., 1990; Sigler et al., 2002; Rummel et al., 2007; Nguyen et al., 2015). The deposition flux of isoprene to the forest canopy and ground surface ( $D$ in Eq. (1)) is estimated as the product of $\langle\mathrm{ISOP}\rangle_{M L}$ and a deposition velocity $\left(V_{d, \mathrm{ISOP}}\right)$

$D=\langle\mathrm{ISOP}\rangle_{\mathrm{ML}} V_{d, \mathrm{ISOP}}$.

Direct determinations of isoprene deposition to soil are rare and none exists, to our knowledge, for tropical forests. A nighttime $V_{d, \text { ISOP }}$ of $0.25 \mathrm{~cm} \mathrm{~s}^{-1}$ is used in this study, following numerical studies (Karl et al., 2004) for a tropical forest canopy. The daytime deposition was estimated by the resistance analogue model (Eq. (6)) following earlier studies (e.g., Wesely and Hicks, 2000).

$V_{d, \mathrm{ISOP}}=\frac{1}{R_{a}+R_{b}+R_{c}}$

$R_{a}$ is the aerodynamic resistance and $R_{b}$ the quasi-laminar sublayer resistance. The expressions for $R_{a}$ and $R_{b}$ can be found in Eqs. (2) and (4) in the article by Wesely et al. (2002). The results of $R_{a}$ and $R_{b}$ are shown in Table 2.

The canopy resistance $R_{c}$ can be separated into two parallel paths as
Table 2

The monthly averaged aerodynamic resistance $\left(R_{a}\right.$ in $\left.\mathrm{s} \mathrm{m}^{-1}\right)$ and quasi-laminar sublayer resistance $\left(R_{b}\right.$ in $\left.\mathrm{s} \mathrm{m}^{-1}\right)$ for isoprene.

\begin{tabular}{lllll}
\hline & June & September & December & January \\
\hline$R_{a}$ & $11 \pm 6$ & $8 \pm 3$ & $13 \pm 12$ & $13 \pm 9$ \\
$R_{b}$ & $14 \pm 6$ & $14 \pm 5$ & $15 \pm 7$ & $15 \pm 6$ \\
\hline
\end{tabular}

shown in Eq. (7) (Nguyen et al., 2015).

$\frac{1}{R_{c}}=\frac{1}{R_{s}+R_{m}}+\frac{1}{R_{\text {cut }}}$

$R_{s}, R_{m}$, and $R_{\text {cut }}$ are stomatal, mesophyll and cuticle resistances respectively. During the daytime when leaf-level isoprene emission occurs through the stomata, the stomatal and mesophyll resistances are assumed to be infinite for isoprene. Therefore, the canopy resistance $R_{c}$ is equal to the cuticle resistance $R_{\text {cut }}$. Due to the lack of information for estimating $R_{\text {cut }}$, the well-documented cuticle resistance for ozone (e.g., Fuentes, 1992; Zhang et al., 2003) was used as an analog $\left(R_{\text {cut,ozone }}\right)$ to isoprene. The values of $R_{\text {cut,ozone }}$ range from 400 to $6000 \mathrm{~s} \mathrm{~m}^{-1}$, yielding small daytime deposition velocity $V_{d, \text { ISOP }}$ of $0.02-0.2 \mathrm{~cm} \mathrm{~s}^{-1}$. By applying this range of $V_{d \text {,ISOP }}$ to Eqs. (5) and (1), we found that the daytime deposition only accounts for less than $4 \%$ of the emitted isoprene (i.e., $(D / E) \leq 4 \%$ in Eq. (1)). Therefore, the daytime deposition of isoprene is neglected in this study (Verver et al., 2000; Hurst et al., 2001). Deposition for other highly reactive gases is not considered in the numerical model. The zero-dimensional model also requires the value of $\mathrm{O}_{3}$ dry deposition $\left(V_{d, \mathrm{O}_{3}}\right)$ to foliage and ground surface. Tropical forests contribute to the $\mathrm{O}_{3}$ sink via the surface deposition process (Fan et al., 1990; Sigler et al., 2002; Rummel et al., 2007). In this study, the $V_{d, \mathrm{O}_{3}}$ values of $1.53 \mathrm{~cm} \mathrm{~s}^{-1}$ and $0.57 \mathrm{~cm} \mathrm{~s}^{-1}$ for daytime and nighttime, respectively, are used (Freire et al., 2017).

The entrainment of air from the residual layer or free atmosphere to the mixed layer can influence the temporal variability of isoprene (Fig. 1). The entrainment flux ( $F_{e}$ in Eq. (1)) is estimated following previous studies (Nappo and van Dop, 1994).

$F_{e}=\frac{\partial z_{i}}{\partial t}\left(\langle\text { ISOP }\rangle_{\mathrm{ML}}-\langle\text { ISOP }\rangle_{\mathrm{RL}}\right)$

At 18:00 h local time (LT) a fraction of isoprene stays in the residual layer where isoprene remains decoupled to the surface until the next morning when it is transported into the shallow mixed layer by entrainment (Verver et al., 2000). Therefore, the $\langle\text { ISOP }\rangle_{R L}$ is assumed to be the observed isoprene at $18: 00 \mathrm{~h}$ and thereafter remains invariant with time. Due to the zero-dimensional modeling approach, the effect of convective detrainment cannot be explicitly included. The $z_{i}$ in Eq. (1) is determined using (Stull, 1988)

$z_{i}=\sqrt{\frac{2(2 C+1)}{\gamma_{\theta_{V}}} \int_{0}^{t}\left(\overline{w^{\prime} \theta_{V}^{\prime}}\right)_{s}}$.

The entrainment parameter $(C)$, defined as the ratio of kinematic heat fluxes at the mixed layer top to the surface $\left(\left(\overline{w^{\prime} \theta_{V}^{\prime}}\right)_{z_{i}} /\left(\overline{w^{\prime} \theta_{V}^{\prime}}\right)_{s}\right)$, is set to 0.2 (Strong et al., 2005). The environmental lapse rate $\left(\gamma_{\theta_{V}}\right)$ in the free atmosphere is assigned the value of $0.004 \mathrm{~K} \mathrm{~m}^{-1}$. Calculations of $z_{i}$ start when $\left(\overline{w^{\prime} \theta_{V}^{\prime}}\right)_{s}$ becomes a positive quantity, typically around 8:00 h, and end when $\left(\overline{w^{\prime} \theta_{V}^{\prime}}\right)_{s}$ turns negative, usually close to sunset $(17: 30 \mathrm{~h})$. In the absence of measurements, the initial value of $z_{i}$ is assumed to be $100 \mathrm{~m}$. The convective velocity scale $\left(w_{*}=\left[\left(\mathrm{g} / \overline{\theta_{V}}\right)\left(\bar{w}^{\prime} \theta_{V}^{\prime}\right)_{s} z_{i}\right]^{1 / 3}, \mathrm{~g}\right.$ is the acceleration due to gravity) was estimated to determine the overturning time scales in the boundary layer.

Influences of chemical reactions $\left(f_{\text {Chem }}\right)$ on the temporal changes in isoprene levels are investigated using a photochemical module, known as the Regional Atmospheric Chemistry Mechanism, version 2 (RACM2, Goliff et al., 2013). The RACM2 includes 117 chemical species and 356 chemical reactions. The mechanism incorporates 17 stable inorganic 
Table 3

Initial mixing ratios (in ppbv) of isoprene, ozone and nitric oxide (NO) during the months considered in the numerical simulations.

\begin{tabular}{lllll}
\hline \multirow{2}{*}{ Chemical species } & \multicolumn{4}{l}{ Month of the year } \\
\cline { 2 - 5 } & June & September & December & January \\
\hline Isoprene & 1.5 & 3.0 & 3.2 & 1.5 \\
Ozone & 8.0 & 11.3 & 8.0 & 7.0 \\
Nitric oxide & 0.2 & 0.35 & 0.2 & 0.15 \\
\hline
\end{tabular}

species, 4 inorganic intermediates, 54 stable organic species, and 42 organic intermediates. Chemical species with similar molecular structures are aggregated into one model species. For example, the RACM2 species API represents $\alpha$-pinene and other cyclic terpenes with one double bond, and LIM represents d-limonene and other cyclic dieneterpenes. However, RACM2 explicitly considers the chemistry of isoprene. Thirty three molecules undergo photolysis in RACM2 and their photolysis frequencies are calculated using tested algorithms (Madronich and Flocke, 1999; Seefeld and Stockwell, 1999). The cross section and quantum yields are taken from previous studies (Sander et al., 2006).

The zero-dimensional model (Eq. (1)) is executed with monthly averaged $E$ and depths of the nocturnal stable boundary layer (nighttime) and $z_{i}$ (daytime) to reproduce the mean diel variations of isoprene for months when isoprene measurements are available. Monthly averages of in situ isoprene and $\mathrm{O}_{3}$ concentration measurements, made at $00: 00 \mathrm{~h}$, are used to initialize the model for each month (Table 3 ). During the rainy season at the study site, NO mixing ratios remain predominantly less than $0.4 \mathrm{ppbv}$ (Fuentes et al., 2016). Therefore, the initial NO mixing ratio of $0.2 \mathrm{ppbv}$ is used for June and December. Initial NO mixing ratios for September and January are then adjusted to match $\mathrm{O}_{3}$ observations (Table 3). Emissions of NO are assumed to be $1.0 \times 10^{-5} \mathrm{ppb} \mathrm{min}^{-1}$ for June, December and January and are adjusted to $1.0 \times 10^{-4} \mathrm{ppb} \mathrm{min}^{-1}$ to match $\mathrm{O}_{3}$ observations in September. These initial levels and emissions of NO result in the modeled layer-averaged $\mathrm{NO}$ mixing ratios at $12: 00 \mathrm{~h}$ of approximately $0.05 \mathrm{ppbv}$ which is the prevailing value observed in the undisturbed rain forest (Torres and Buchan, 1988; Liu et al., 2016). For other chemical species, reported values from previous studies (Hu et al., 2015; Jardine et al., 2015) are used for the initialization of the zero-dimensional model (see Supplement I).

The model was executed at a time step of $30 \mathrm{~min}$ to produce concentrations of all chemical species. The emission term $\left(\frac{E(t)-F_{e}(t)}{z_{i}(t)}\right)$, the chemical sink $\left(f_{\text {Chem }}\right)$, and the resultant temporal changes in isoprene $\left(\frac{\partial\langle\mathrm{ISOP}\rangle_{\mathrm{ML}}}{\partial t}\right)$ in Eq. (1) are then used to investigate the relative contribution of each process to the total rate of change of isoprene (Fig. 1). Mean diel cycles of isoprene concentrations are simulated using the zero-dimensional model with monthly averages of $E$ and $z_{i}$. It is therefore necessary to assess the uncertainties associated with the dayto-day variations in $\mathrm{E}$ and $z_{i}$. Following previous methods (de Arellano et al., 2009), several experiments were done to determine the likely influences of each variable $\left(E, z_{i}\right.$ and $\left.\langle\mathrm{ISOP}\rangle_{R L}\right)$ on isoprene cycles by varying only one variable within its expected range.

Chemical processes such as $\mathrm{HO}$ recycling, segregation of isoprene- $\mathrm{HO}$, and NO levels can also influence isoprene concentrations. Reactions of $\mathrm{O}_{3}$ with isoprene and monoterpenes can generate $\mathrm{HO}$ (Paulson and Orlando, 1996) whose yields depend on ambient NO levels (Stone et al., 2012). In low NO-environments, isoprene oxidation generates isoprene peroxyl radicals (ISOPOOH) which can subsequently react and contribute to the recycling of $\mathrm{HO}$, with suggested values ranging from 30 to 50\% $\mathrm{HO}$ yields (Paulot et al., 2009a; Taraborrelli et al., 2012; Fuchs et al., 2013). To estimate the influences of the regenerated HO on the inferred isoprene levels, sensitivity analyses are performed. As the exact nature of these reactions still remains under investigation, additional HO-recycling is enforced a priori in the existing chemical mechanism as shown in reactions (10) and (11).

$\mathrm{ISOP}+\mathrm{HO} \stackrel{k_{10}}{\longrightarrow}$ ISOPOOH

$\mathrm{ISOPOOH}+\mathrm{HO}_{2} \stackrel{k_{11}}{\longrightarrow} \chi \mathrm{HO}+$ Products

The $\chi$ denotes the fraction of additional HO recycling, which in the current study varies from 0 to $20,40,60,80$, and $100 \%$.

The interplay and the interaction of upward- and downward-moving eddies can produce incomplete mixing of chemical species within the ABL. Segregation of chemical reactants results in response to different spatial distribution of sources and sinks of isoprene and oxidants, and is hypothesized to affect isoprene oxidation within the ABL (e.g., Krol et al., 2000; Verver et al., 2000). The intensity of segregation $\left(I_{s}\right)$ for two chemical species $(A, B)$ can be estimated using Eq. (12) (Brodkey, 1981).

$I_{s, A+B}=\frac{\overline{A^{\prime} B^{\prime}}}{\bar{A} \bar{B}}$

Covariances between the chemical species $\left(\overline{A^{\prime} B^{\prime}}\right)$, averaged over a given time period (the over bar denotes temporal averages), serve as measures of the segregation of the gases compared to their averaged quantities $(\bar{A}, \bar{B})$. Spatial segregation of chemical species can lead to negative $I_{s}$ while colocation of their source distribution causes $I_{s}$ to be positive. In the context of the zero-dimensional modeling, effects of segregation are typically included (e.g., Ouwersloot et al., 2011) through the introduction of effective reaction rate coefficients $\left(k_{\text {eff, } I_{s}}\right)$. The method uses $I_{s}$ to reduce the default reaction rate coefficient. In the case of the reaction of isoprene with $\mathrm{HO}$, from the second-order reaction

ISOP $+\mathrm{HO} \stackrel{k_{13}}{\longrightarrow}$ Products

the effective reaction rate $R$ can be determined as

$R=k_{13}\left(1+I_{s, \mathrm{ISOP}+\mathrm{HO}}\right)\langle\mathrm{ISOP}\rangle_{\mathrm{ML}}\langle\mathrm{HO}\rangle_{\mathrm{ML}}=k_{\mathrm{eff}, I_{S}}\langle\mathrm{ISOP}\rangle_{\mathrm{ML}}\langle\mathrm{HO}\rangle_{\mathrm{ML}}$

In the tropical convective boundary layer, previous studies reported isoprene and HO segregation intensities of $7-13 \%$ based on large eddy simulation results (Ouwersloot et al., 2011), 13-43\% from aircraft profile measurements, and up to $50 \%$ from regional chemical model calculations (Karl et al., 2007; Butler et al., 2008). Ad hoc $I_{s, \mathrm{ISOP}+\mathrm{HO}}$ values of $-0.1,-0.2,-0.3,-0.4$ and -0.5 are used in this study to estimate the potential impacts of segregation effects and incomplete air mixing on the temporal variability of ambient isoprene levels.

Nitric oxide plays an essential role in the chemistry of biogenic hydrocarbons and can regulate the concentrations of $\mathrm{O}_{3}$ and HO. In addition, NO levels to some extent dictate the pathway of isoprene photochemical reactions (Liu et al., 2016). Therefore, simulation experiments are executed with varying NO emission rates, ranging from $1 \times 10^{-5}$ to $4 \times 10^{-4} \mathrm{ppbv} \mathrm{min}^{-1}$, to examine the impacts of $\mathrm{NO}$ on the inferred isoprene levels.

\section{Results and discussion}

Observed isoprene mixing ratios along with the concurrent meteorological and phenology data are presented and discussed. Zero-dimensional model results are presented to investigate the processes controlling diel evolution of isoprene mixing ratio. Uncertainties associated with isoprene emission, boundary layer evolution, and chemistry are assessed.

\subsection{Influences of meteorological conditions on diurnal cycles of isoprene}

During 2014, the study site experienced only small seasonal variations in air temperature, with averaged monthly oscilations of about 

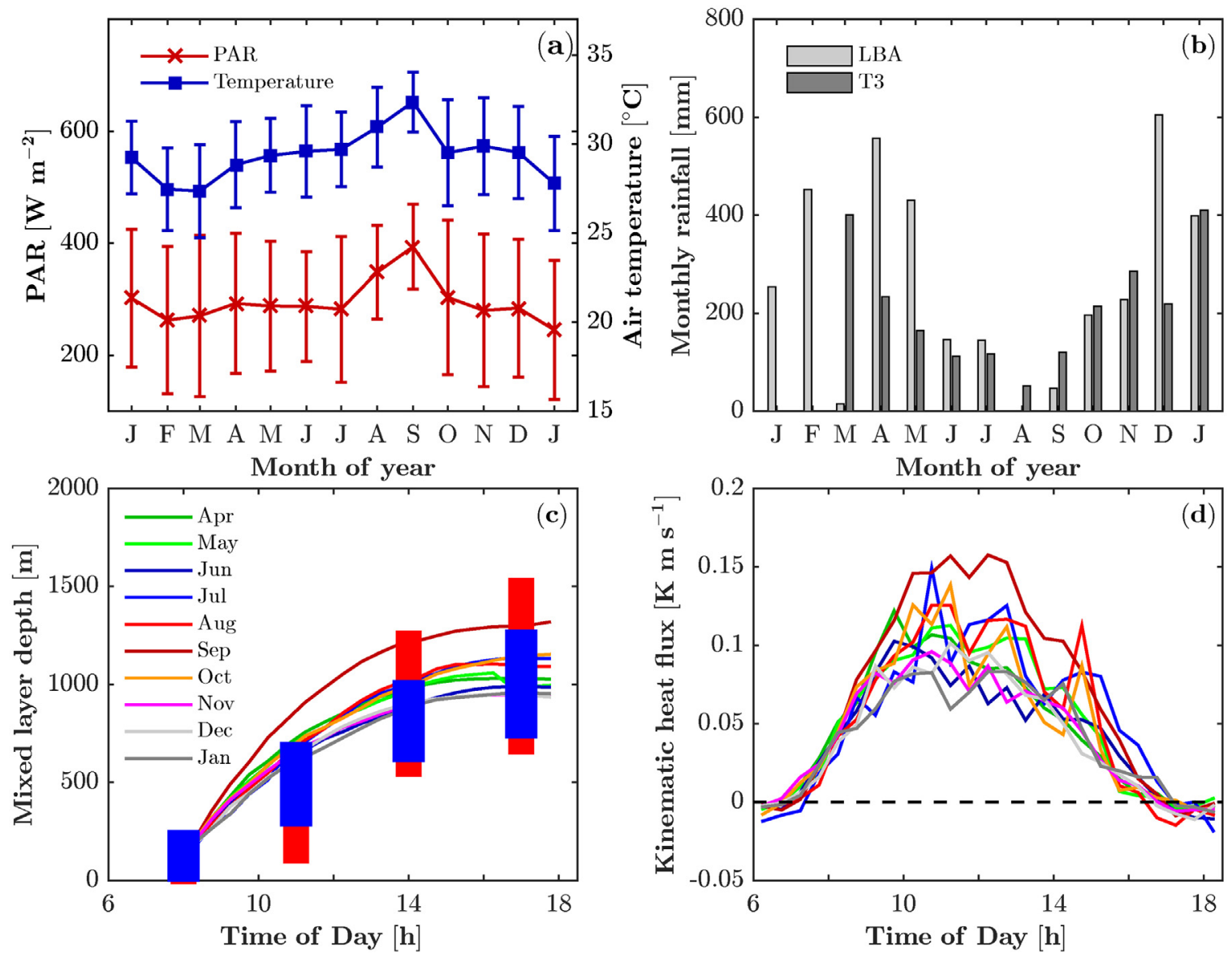

Fig. 2. Meteorological conditions during January 2014 to January 2015 at the study site: (a) Monthly averages of daytime (10:00 to 14:00 h) air temperature (blue) and photosynthetically active radiation (PAR, red) at $40 \mathrm{~m}$ above the ground; (b) Monthly accumulated rainfall from LBA (light gray) and T3 (dark gray) sites (data gaps for January, February and March); (c) Monthly averages of half hourly mixed layer depth $\left(z_{i}\right)$. Bars denote the ranges of $z_{i}$ derived from rawinsoundings done over an undisturbed tropical forest during wet (blue) and dry (red) seasons (Fisch et al., 2004); (d) Monthly averages of half hourly kinematic heat fluxes at $40 \mathrm{~m}$ above the ground. (For interpretation of the references to color in this figure legend, the reader is referred to the web version of the article.)

$5{ }^{\circ} \mathrm{C}$. Maximum ambient temperature $\left(32.4 \pm 1.7^{\circ} \mathrm{C}\right)$ occurred at the end of the dry season in September (Fig. 2a) when the highest averaged PAR levels reached $394 \pm 76 \mathrm{~W} \mathrm{~m}^{-2}$ (Fig. 2a) in response to reduced cloudiness and storms. In contrast, the lowest radiation and temperature were observed in January $2015\left(245 \pm 124 \mathrm{~W} \mathrm{~m}^{-2}\right.$, $27.8 \pm 2.7^{\circ} \mathrm{C}$, respectively) (Fig. 2a). June and July were transition months and they experienced mixed features of both wet and dry seasons with a notable reduction in monthly rainfall but similar light and temperature conditions compared to the preceding months (Fig. 2a and b). The Amazon rain forest is characterized by high rainfall year round but is punctuated with reduced rainy periods when total monthly rainfall drops below $100 \mathrm{~mm}$ (Sombroek, 2001). The study site experiences considerable inter-annual rainfall variability (Malhi, 2002). In 2014, August and September were considered dry periods with total monthly rainfall of $<100 \mathrm{~mm}$ whereas October to May represented the peak of the rainy season with maximum monthly rainfall of $600 \mathrm{~mm}$ (Fig. 2b). Kinematic heat fluxes, derived from eddy covariance measurements, exhibited strong diurnal variations with maximum values of $0.15 \mathrm{~K} \mathrm{~m} \mathrm{~s}^{-1}$ generally attained during $11: 00$ to $13: 00 \mathrm{~h}$ (Fig. 2d). During the morning hours, rapid increases in the kinematic heat fluxes occurred due to reduced cloudiness. Mean maximum heat fluxes exceeding $0.10 \mathrm{~K} \mathrm{~m} \mathrm{~s}^{-1}$ prevailed during the dry season in response to the greater incoming solar irradiance and surface heating (Fig. 2a and d). Utilizing knowledge of kinematic heat fluxes, the estimated depth of the ABL mixed layer exhibited pronounced diurnal and seasonal patterns, with $z_{i}$ values ranging from $100 \mathrm{~m}$ up to $1300 \mathrm{~m}$ (Fig. 2c). From 8:00 to $14: 00 \mathrm{~h}$, the mixed layer rapidly developed with time in response to increasing surface heating (Fig. 2d) and from 14:00 to 18:00 h the mixed layer depth remained relatively stationary while the kinematic heat fluxes decreased, with the extra energy from entrainment to support the convective ABL. Although the modeling of mixed layer did not consider day-to-day variations in the advection or large-scale atmospheric dynamics, estimates of the mixed layer depth (Fig. 2c) reasonably agreed with values derived from upper air soundings made over the rain forest in the southwest Amazonia (Fisch et al., 2004). Typical $z_{i}$ values derived by Fisch et al. (2004) using rawinsondes are presented (Fig. 2c) in order to compare them with the estimates obtained in this study.

Isoprene mixing ratios over the rain forest exhibited strong seasonal variability in response to meteorological conditions and plant phenology. Maximum averaged isoprene levels of about $10 \mathrm{ppbv}$ prevailed during September (Fig. 3b) and coincided with ambient temperature of $>30{ }^{\circ} \mathrm{C}$ that promoted enhanced emissions. Throughout the growing season, variations in leaf area and foliage phenology also influenced isoprene emissions (Fig. 3a; see below). On daily time scales, isoprene mixing ratios showed well-defined diel cycles with maximum levels observed in the early afternoon and minimum just before sunrise (Fig. 3a-d) in response to daytime emissions from the rain forest. Isoprene mixing ratios increased with PAR levels (Fig. 3e-l) due to the influences of light on isoprene biosynthesis. The relationship between isoprene levels and PAR (Fig. 3e-h) exhibited some hysteresis in the variability of isoprene. In the morning hours, isoprene levels increased with PAR whereas in the afternoon isoprene mixing ratios declined along a different trajectory after PAR reached the daily maximum 

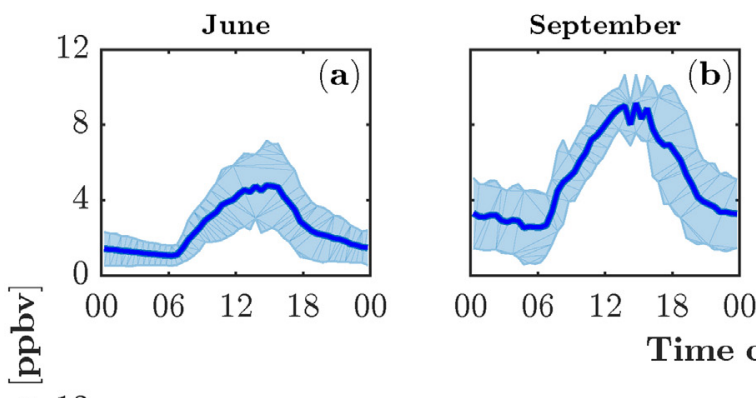

$\begin{array}{lllll}00 & 06 & 12 & 18 & 00\end{array}$ Time of day $[h]$

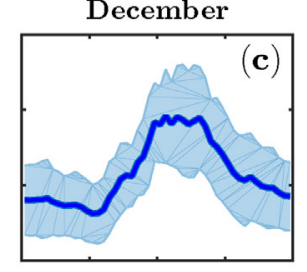

$\begin{array}{lllll}00 & 06 & 12 & 18 & 00\end{array}$
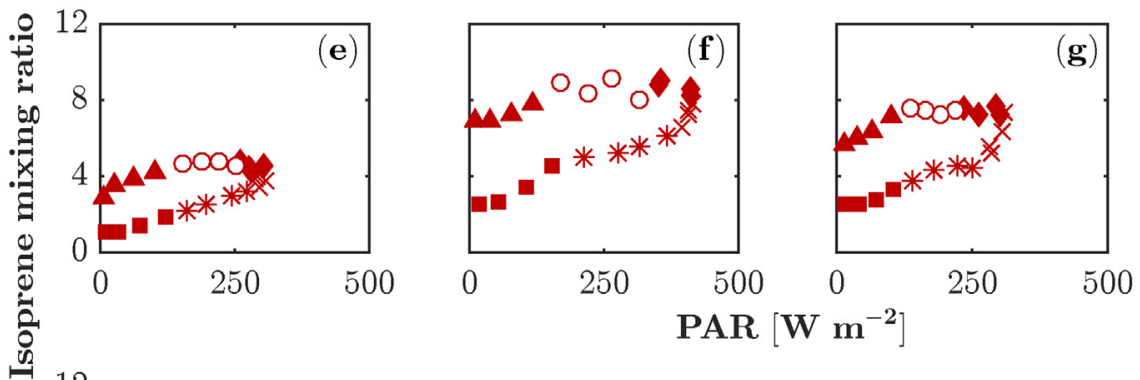

PAR $\left[\mathbf{W ~ ~ m ^ { - 2 } ]}\right.$

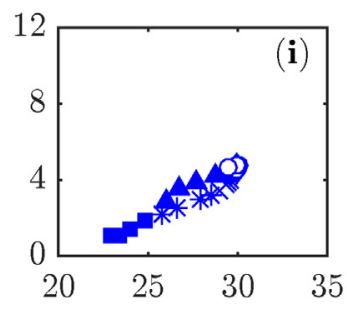

0

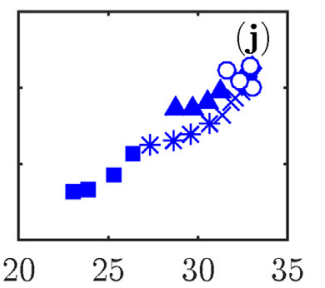

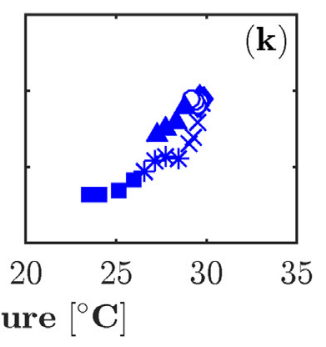
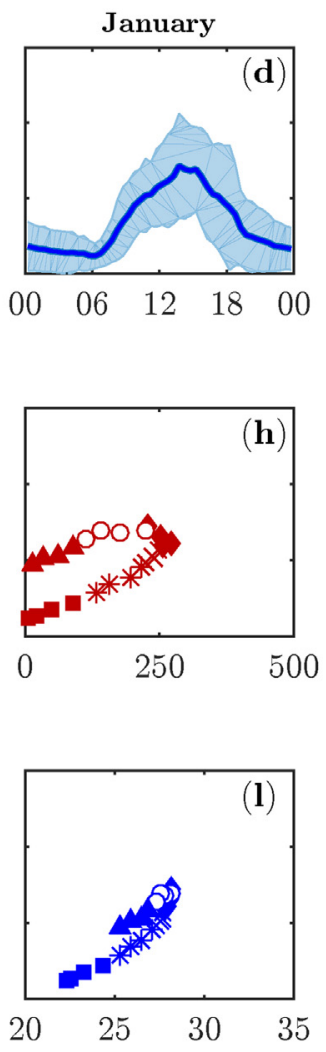

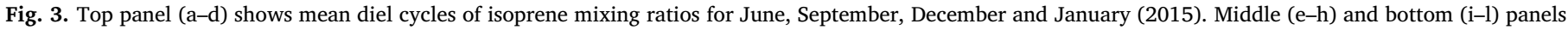

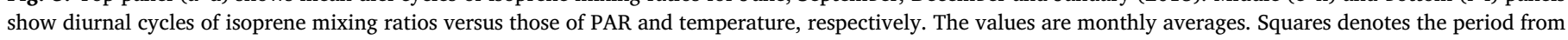
6:00 to $8: 00 \mathrm{~h}$, stars $8: 00$ to $10: 00 \mathrm{~h}$, crosses $10: 00$ to $12: 00 \mathrm{~h}$, diamonds $12: 00$ to $14: 00 \mathrm{~h}$, open circles $14: 00$ to $16: 00 \mathrm{~h}$, and triangles $16: 00$ to $18: 00 \mathrm{~h}$.

values. These PAR-isoprene patterns result partly owing to the thermodynamic characteristics of the local atmospheric boundary layer (Fuentes and Wang, 1999). Diurnal hysteresis between evapotranspiration and vapor pressure deficit also prevail in many ecosystems (Zhang et al., 2014). In the morning hours, emissions occur when there are shallow boundary layers whose isoprene content is low $(<2$ ppbv) due to the combined influences of surface deposition and no emissions from the previous night. Because of the weak convection in the morning, the emitted isoprene remains mixed in a relatively small atmospheric volume whose depth is defined by the shallow mixed layer. In contrast, during the afternoon isoprene emission takes place when the atmospheric boundary layer is deeper and remains relatively well mixed due to the strong convection. Consequently, isoprene levels tend to decreased with reducing PAR along a path exhibiting greater values compared to the morning quantities (Fig. $3 \mathrm{e}-\mathrm{h}$ ). Isoprene mixing ratios correlated well with air temperature in both morning and afternoon hours (Fig. 3i-1).

\subsection{Influences of foliage phenology on isoprene seasonal patterns}

Over the course of the 2014 growing season, MODIS-derived LAI varied from 4.5 to $6.5 \mathrm{~m}^{2} \mathrm{~m}^{-2}$ (Fig. 4a). Based on in situ observations (Wu et al., 2016), the low LAI values obtained for June and July resulted due to the combination of high amounts of leaf senescence and abscission, and development of new foliage (Fig. 4a). The leaf loss in June was greater than the new leaf production. Just before the onset of dry seasons in July, new leaf production exceeds the simultaneous litterfall, which resulted in the significant net increase of LAI from July to August. The significant reductions in LAI identified during June coincided with the onset of the dry season (Fig. 2b) and indicated shifts of leaf age composition toward new leaves (Fig. 4a). In addition, reductions in LAI and shifts toward young foliage corresponded with the observed lowest isoprene and highest methanol levels (Fig. 4b). These results are consistent with the fact that young leaves ordinarily exhibit low isoprene (Monson et al., 1994; Fuentes and Wang, 1999) and high methanol emissions (Alves et al., 2014; Jardine et al., 2016). With the start of the rainy season in September (Fig. 2b) new leaves expanded and matured throughout the growing season, resulting in larger LAI during September to January (Fig. 4a). Wu et al. (2016) showed similar foliage patterns that new leaves emerge in June and mature during both the dry period (from August to September) and the beginning of the wet season (from September to November). Such simultaneous temporal patterns in foliage quantity and phenology seemed consistent with the seasonal isoprene levels observed in September, December and January (Fig. 4b). Median isoprene mixing ratios, calculated for the period ranging from 10:00 to 14:00 h, exhibited strong seasonal patterns, with maximum and minimum values observed in September and June, respectively (Fig. 4b). Percentage changes in isoprene mixing ratios relative to June revealed major seasonal variations, ranging from 10 to $80 \%$ (Fig. $4 \mathrm{c}$ ). The percentage changes in the temperature response $\left(\gamma_{T}\right)$ with respect to June were also plotted (Fig. 4c) in order to quantitatively show the influences of temperature on the increased isoprene mixing ratios. In September, both meteorological factors and LAI contributed to the $80 \%$ increase in isoprene, with temperature being the predominant factor as shown by the $110 \%$ increase in $\gamma_{T}$. However, isoprene mixing ratios were $60 \%$ and $10 \%$ greater in December and January than in June despite the similar meteorological conditions observed during these months (Fig. 4c). Therefore, temperature and PAR levels did not consistently drive isoprene mixing ratios. In fact, the increases in LAI invariably followed those in isoprene mixing ratios (Fig. 4c), suggesting amount of foliage and phenology consistently tracked the seasonality of isoprene mixing 

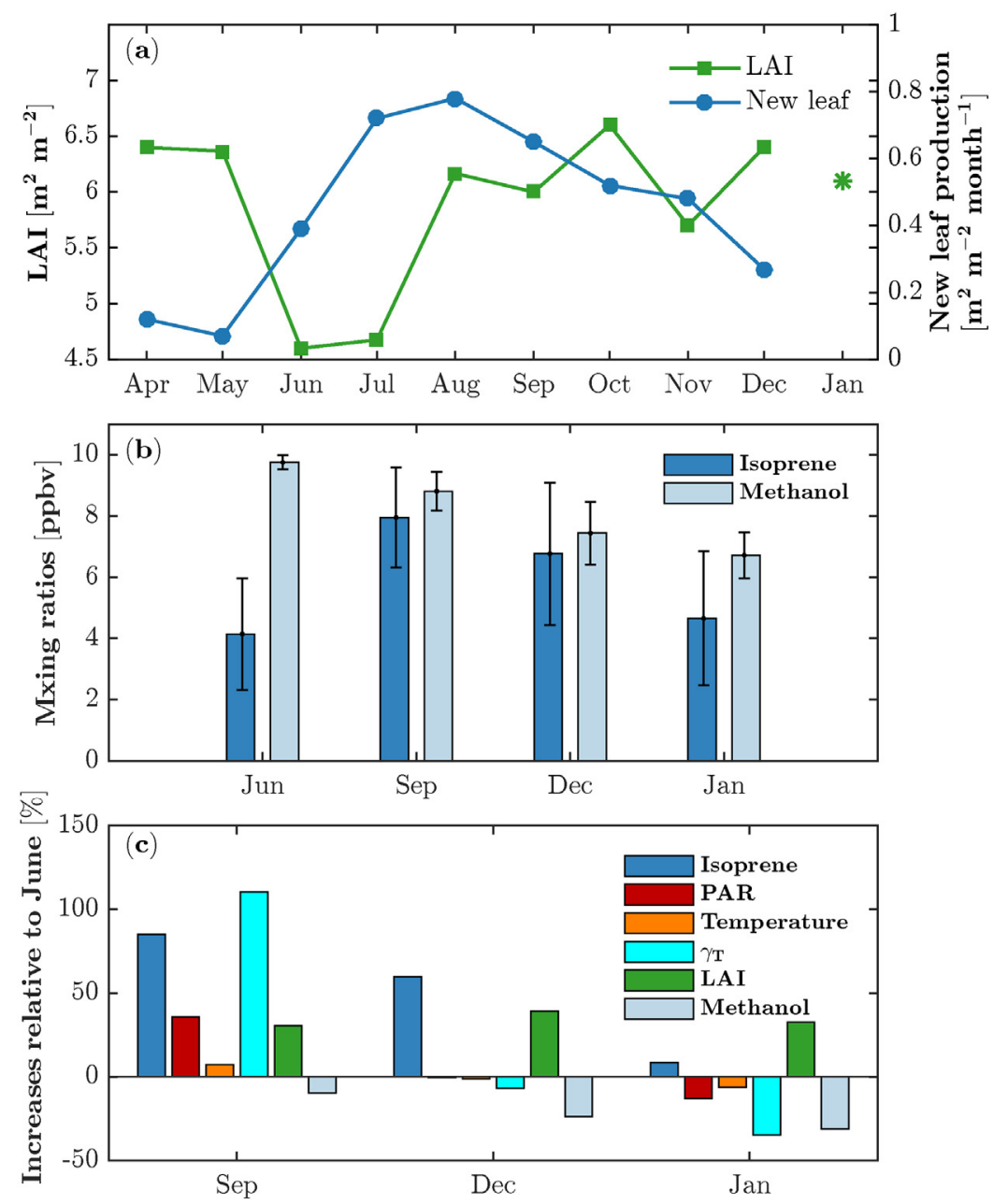

Fig. 4. (a) Monthly leaf area index (LAI) from the tile of h11v09 of the Terra MODIS (moderate-resolution imaging spectroradiometer) for the measurement period (dark green squares); dark green asterisk represents January 2015 LAI from Wu et al. (2016); New leaf production (blue circles) at the same site (ZF2) from Wu et al. (2016); (b) Median daytime (10:00 to 14:00 h) isoprene and methanol mixing ratios for June, September, December and January; (c) Percentage increases in isoprene, PAR, temperature, gamma-temperature $\left(\gamma_{\pi}\right)$, LAI, and methanol relative to June. (For interpretation of the references to color in this figure legend, the reader is referred to the web version of the article.)

ratios.

In the rain forest, isoprene emission algorithms need to consider seasonal variations of active biomass and changes in constitutive basal emissions associated with foliage age. To quantify the effects of foliage amounts and leaf age on isoprene emissions, the information presented above (Figs. 3 and 4) were included in the isoprene emission algorithm described in Section 2.3. Even though suitable environmental conditions and adequate amounts of active biomass prevailed in June, maximum isoprene emissions only reached $5 \mathrm{mg} \mathrm{m}^{-2} \mathrm{~h}^{-1}$ (Fig. 5a). Highest emission rates of approximately $11 \mathrm{mg} \mathrm{m}^{-2} \mathrm{~h}^{-1}$ estimated for September (Fig. 5a) resulted mainly due to temperature and PAR as well as greater amounts of foliage quantity and basal isoprene biosynthesis. The almost identical meteorological conditions observed during December and June (Fig. 2a) indicated that the greater isoprene emissions estimated for December occurred in response to foliage attaining a greater capacity to emit isoprene. On the whole, these results (Fig. 5a) illustrate that aggregate foliage phenology as expressed in the basal emission rates, considering the relatively small variability of environmental drivers in the rain forest, is one factor contributing to the isoprene seasonality. Estimates of isoprene emissions are in good agreement with previously reported canopy-scale isoprene fluxes (Rinne et al., 2002; Kuhn et al., 2007).

To corroborate the influences of foliage phenology on estimated isoprene emissions, three additional numerical simulations were performed. The first simulation included a constant LAI of $6 \mathrm{~m}^{2} \mathrm{~m}^{-2}$ and an unchanged leaf age while the second experiment involved the observed LAI (shown in Fig. 4a). These two simulations indicated that isoprene emissions barely changed with amount of active biomass when LAI exceeded $4.5 \mathrm{~m}^{2} \mathrm{~m}^{-2}$ (Fig. 5b). As shown in previous studies (Guenther et al., 2006), the emission algorithm provides nearly constant isoprene fluxes for LAI greater than $5 \mathrm{~m}^{2} \mathrm{~m}^{-2}$ due to the insufficient PAR levels reaching the lower forest canopy. The third simulation incorporated the observed LAI and variable isoprene basal emissions to reflect leaf age (as done in Fig. 5a). Results indicated that the maximum isoprene emission rates decreased by $6 \%$ in June and increased by $12 \%$ in September, December and January when leaf phenology was considered in the emission algorithm. Results (Fig. 5b) indicated that between June and September changes in maximum isoprene emission without leaf age increased from $4 \mathrm{mg} \mathrm{m}^{-2} \mathrm{~h}^{-1}$ to $8 \mathrm{mg} \mathrm{m}^{-2} \mathrm{~h}^{-1}$ while emission changes associated with the leaf age algorithm were small (from $8 \mathrm{mg} \mathrm{m}^{-2} \mathrm{~h}^{-1}$ to $9 \mathrm{mg} \mathrm{m}^{-2} \mathrm{~h}^{-1}$ ). Environmental conditions predominantly explained the large emission changes between June and September. Seasonal differences in emissions are linked to new leaves with low isoprene emission capacity in June, leaves grow mature in about six months and incrementally augment their photosynthetic capacity and isoprene biosynthesis, and leaves become old from January until next June which is just before the start of the dry season (Wu et al., 2016). 

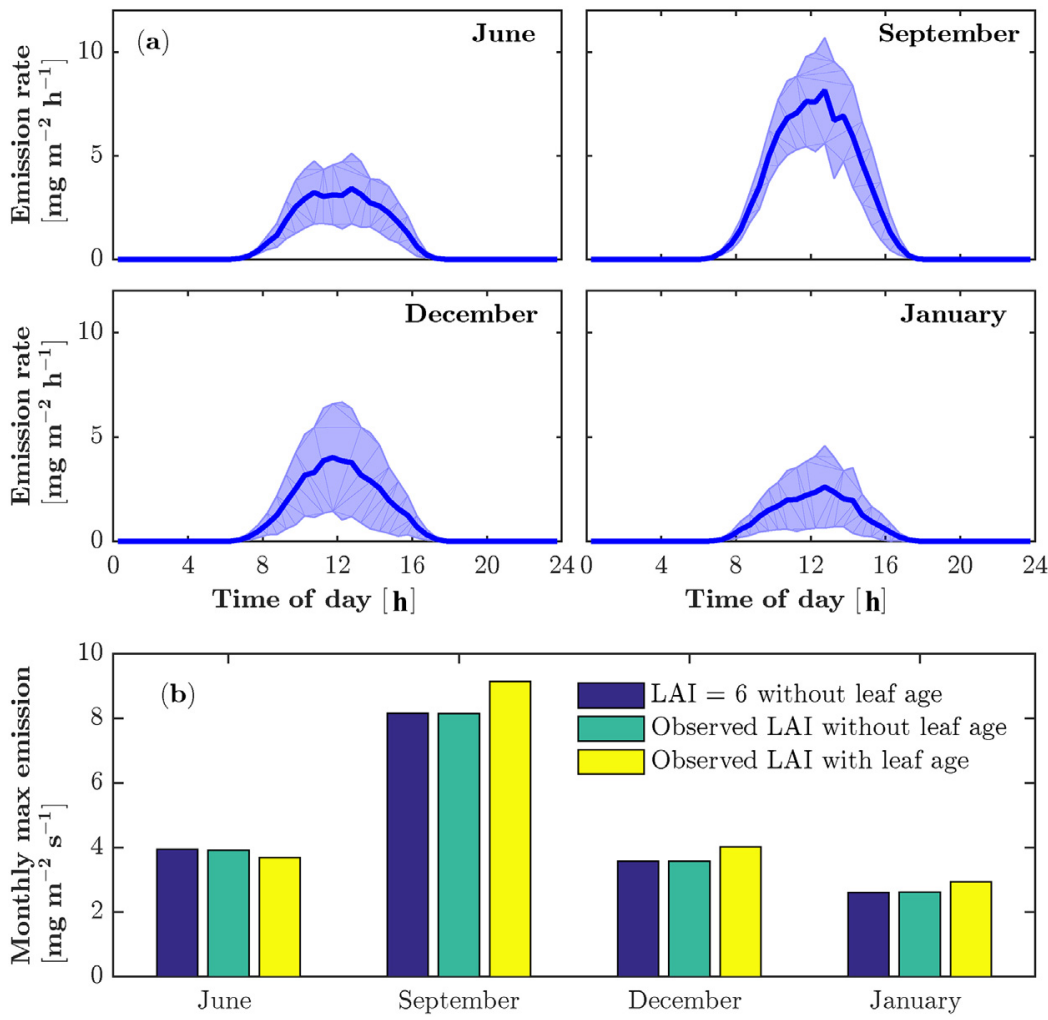

Fig. 5. (a) Estimates of isoprene emission rates for June, September, December and January (2015). Solid lines denote the monthly averages of modeled emission rates and shaded areas represent the standard deviations. (b) The modeled responses of emission rates to leaf area index (LAI) and leaf age in the algorithm of isoprene emission.

\subsection{Processes controlling the isoprene diel cycles}

Once released from leaves, isoprene molecules can undergo chemical reactions, surface deposition, and turbulent transport in the atmospheric boundary layer. With the zero-dimensional model (Goliff et al., 2013), it was possible to investigate the influences of each aforementioned process on isoprene temporal variations. Model results closely matched isoprene (Fig. 6a-d) and ozone (Fig. 6e-h) levels for the chosen months of the simulations. Comparisons of the typical atmospheric lifetime of isoprene, which is in the order of $1-2 \mathrm{~h}$, with the convective boundary layer overturning timescales (typically $z_{i} / w_{*} \sim 10 \mathrm{~min}$ ) indicated that isoprene remained relatively well mixed in the ABL as demonstrated by previous field studies (Karl et al., 2007; Fuentes et al., 2016).

Hydroxyl radicals, which serve as the main chemical sink of isoprene, were estimated based on the photolysis of ozone $\left(\mathrm{O}_{3}+\right.$ Light $\rightarrow$ $\mathrm{O}_{2}+\mathrm{O}\left({ }^{1} \mathrm{D}\right)$ ) and reactions of the resulting electronically excited atomic oxygen $\left(\mathrm{O}\left({ }^{1} \mathrm{D}\right)\right)$ with water vapor $\left(\mathrm{O}\left({ }^{1} \mathrm{D}\right)+\mathrm{H}_{2} \mathrm{O} \rightarrow \mathrm{HO}+\mathrm{HO}\right.$; photolysis of chemical species such as nitric acid and formaldehyde also contributed to the HO formation). Simulated maximum HO concentrations and photolysis rates $\left(\mathrm{NO}_{2}\right)$ did not occur at the same time. Instead, estimated $\mathrm{HO}$ concentrations reached maximum values around 09:00 h when ozone levels remained relatively low while maximum photolysis rates prevailed around noon time (Fig. 6i-1). Early in the morning, abrupt increases in HO concentrations occurred due to rapid increases in solar irradiance, the preponderance of shallow atmospheric boundary layers, and low isoprene levels. Previous studies (Whalley et al., 2011; Taraborrelli et al., 2012) also found similar HO temporal trends. In this case (Fig. 6i-1), temporal patterns in $\mathrm{HO}$ concentrations resulted from the combined effects of diurnal cycles of photolysis, isoprene emissions, and depth of the boundary layer. Highest and lowest HO concentrations happened in September $\left(1.1 \times 10^{6}\right.$ molecules $\left.\mathrm{cm}^{-3}\right)$ and December $\left(6.4 \times 10^{5}\right.$ molecules $\left.\mathrm{cm}^{-3}\right)$, respectively, consistent with the seasonality of ozone. Earlier studies (Whalley et al., 2011) reported averaged maximum HO concentrations of $\sim 2.5 \times 10^{6}$ molecules $\mathrm{cm}^{-3}$ with a day-to-day variability of $\sim 1.5 \times 10^{6}$ molecules $\mathrm{cm}^{-3}$ at $5 \mathrm{~m}$ above the ground in a clearing of a tropical rain forest. This underestimation of HO in the rain forest likely occurred as a consequence that the zero-dimensional model did not account for HO recycling from hydrocarbon oxidation (Taraborrelli et al., 2012; Fuchs et al., 2013) and segregation of isoprene-HO due to incomplete turbulent mixing (Kaser et al., 2015; Kim et al., 2016) (evaluations of these two processes on modeled HO concentrations are discussed in Section 3.4).

In the absence of biomass burning or anthropogenic pollution, the NO levels in central Amazonia exist in the parts per trillion (pptv) range (for the same study period, Liu et al. (2016) reported a mean value of $0.035 \pm 0.032$ ppbv). Soil emissions (Bakwin et al., 1990) in the zerodimensional model were set to yield the range of NO mixing ratios measured at the study site. During the nighttime, the reaction of NO with $\mathrm{O}_{3}$ produced $\mathrm{NO}_{2}$ whose maximum mixing ratios reached $0.5 \mathrm{ppbv}$ (Fig. $6 \mathrm{~m}-\mathrm{p})$. Modeled daytime $(8: 00$ to $16: 00 \mathrm{~h})$ mean NO levels ( $0.06 \mathrm{ppbv}$ for June, $0.05 \mathrm{ppbv}$ for December and January, and $0.07 \mathrm{ppbv}$ for September) closely agreed with measured quantities (see below). In the early morning the NO levels increased rapidly due to the photolysis of $\mathrm{NO}_{2}$ (Jacob and Wofsy, 1988; Torres and Buchan, 1988). The results summarized in Fig. 6 indicated that the zero-dimensional model adequately captured the principal reaction pathways responsible for the oxidation of isoprene.

Contributions of isoprene emissions and entrainment into the ABL $\left(\frac{E(t)-\mathrm{Fe}(t)}{z_{i}(t)}\right)$, and chemical reactions $\left(f_{\text {Chem }}\right)$ were examined to identify the most important controls on the diel cycles of isoprene mixing ratios (Fig. 1). During the nighttime, isoprene emissions and reaction with HO were negligible (Fig. 7a-d) but dry deposition and reaction with nitrate radicals $\left(\mathrm{NO}_{3}\right)$ represented sinks. On average, dry deposition accounted for $78 \%$ of the total nighttime loss of isoprene (not shown) and $\mathrm{NO}_{3}$ played a minor sink role due to its low concentrations. Before 15:00 h, the rate of isoprene change $\left(\frac{\partial\langle\mathrm{ISOP}\rangle_{\mathrm{ML}}}{\partial t}\right)$, due to the dominance of the emission term over the chemical reactions, resulted in a positive quantity. The emission term attained highest values around 7:00 h when isoprene was emitted and entrained (which accounted for $34 \%$ of 

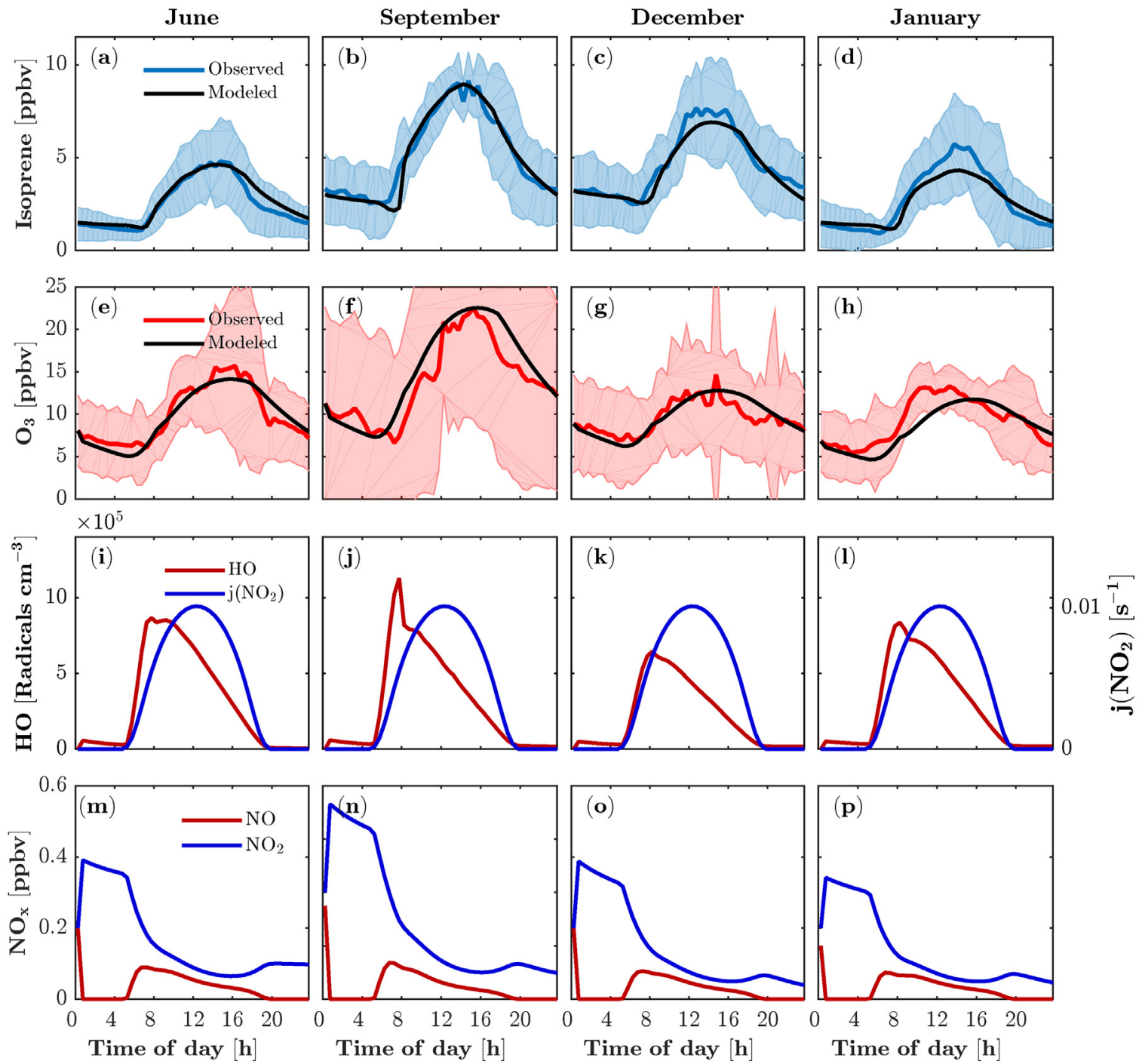

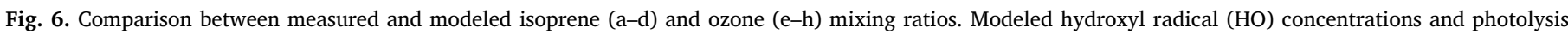
rates of $J\left(\mathrm{NO}_{2}\right)(\mathrm{i}-\mathrm{l})$, and nitrogen oxides $\left(\mathrm{NO}, \mathrm{NO}_{2}\right)$ mixing ratios $(\mathrm{m}-\mathrm{p})$.

the emission at this time) into a shallow boundary-layer and chemical destruction was weak. In contrast, the chemical sink (mostly by HO) reached maximum values around 11:00 $\mathrm{h}$ when both isoprene and HO were abundantly available. Around 15:00 h, emissions and reactions almost reached a balance and gave rise to highest daily isoprene mixing ratios (Fig. 7a-d). Thereafter, chemical consumption dominated as declining isoprene emissions coincided with high $z_{i}$. This budget method (Eq. (1)) failed to capture the precipitous declines of isoprene observed around sunset (Fig. 7a-d), which have been ubiquitously reported for other forested ecosystems (Fuentes et al., 1999; Hurst et al., 2001) and urban sites (Doughty et al., 2015). Hurst et al. (2001) estimated that vertical mixing with isoprene-depleted air probably contributes to the rapid isoprene decay in unpolluted environments. Doughty et al. (2015) concluded that the abrupt isoprene declines depend on nitrate radicals. Altogether this budget analysis revealed that, integrated over the 6:00- to $18: 00$-h period, on average $56 \%$ ( $4.8 \mathrm{ppbv}$ ), $77 \%$ (12.3 ppbv), 69\% (6.2 ppbv), and 69\% (6.2 ppbv) of the emitted isoprene was chemically consumed in June, September, December, and January, respectively (Fig. 7e). These results highlight the necessity and the importance of having reliable knowledge of isoprene reaction pathways so that improved estimates of oxidant and SOA formation can be made for the Amazon rain forest.

\subsection{Sensitivity analysis}

Uncertainties associated with day-to-day variations in $\mathrm{E}, z_{i}$, entrainment, HO recycling, and HO-isoprene segregation are estimated to ascertain the fidelity of simulated mean diel cycles of isoprene. The focus of this analysis is on the sensitivity of each process in influencing the ambient isoprene levels. Therefore, experiments only for June (Fig. 6a) are considered as the control simulation. The estimated $z_{i}$ exhibited large day-to-day variations (Fig. 8a) due to the variability of kinematic heat fluxes, assumed lapse rate in the free atmosphere $\left(\gamma_{\theta_{V}}=4 \mathrm{~K} \mathrm{~km}^{-1}\right)$, and temporal changes in the variations of temperature $\left(\frac{\partial\left(\Delta \theta_{V}\right)}{\partial t}\right)$. Modeled isoprene ambient levels increased by $77 \%$ when hourly $z_{i}$ decreased one standard deviation from its averaged half values $\bar{z}_{i}\left(\bar{z}_{i}-\sigma_{z_{i}}\right)$ (Fig. 8a) whereas the corresponding increase to $\bar{z}_{i}+\sigma_{z_{i}}$ reduced isoprene by $31 \%$ (Fig. $8 \mathrm{~b}$ ). These results indicated that in shallow mixed layers and hence smaller atmospheric mixing volume, isoprene levels can be overestimated. In contrast, in deeper mixed layers and thus greater atmospheric mixing volume, isoprene mixing ratios can be substantially underestimated. In the case of emissions, the simulations of $\bar{E}+\sigma_{E}$ and $\bar{E}-\sigma_{E}$ generated a $78 \%$ increase and a $55 \%$ decrease, respectively, in isoprene mixing ratios (Fig. 8d) compared to the mean quantities. This sensitivity analysis (Fig. $8 \mathrm{c}$ and d) illustrated that even small perturbations of $\bar{z}_{i}$ and $\bar{E}$ can engender substantial deviations in 

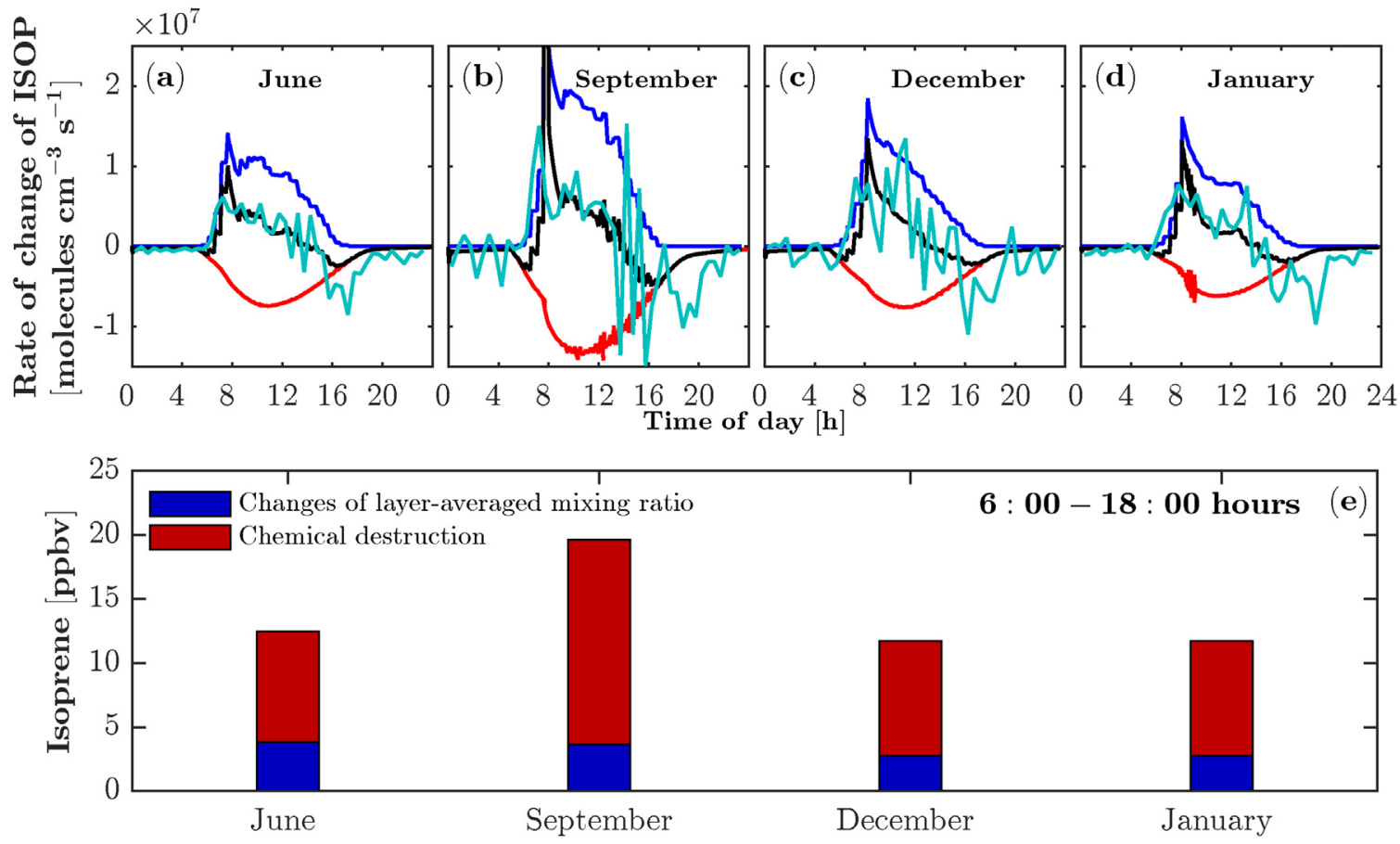

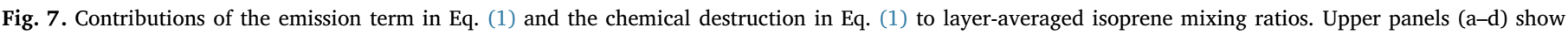

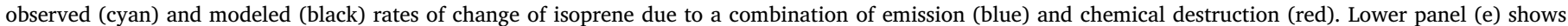

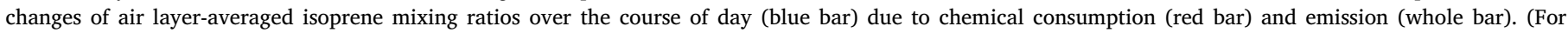
interpretation of the references to color in this figure legend, the reader is referred to the web version of the article.)
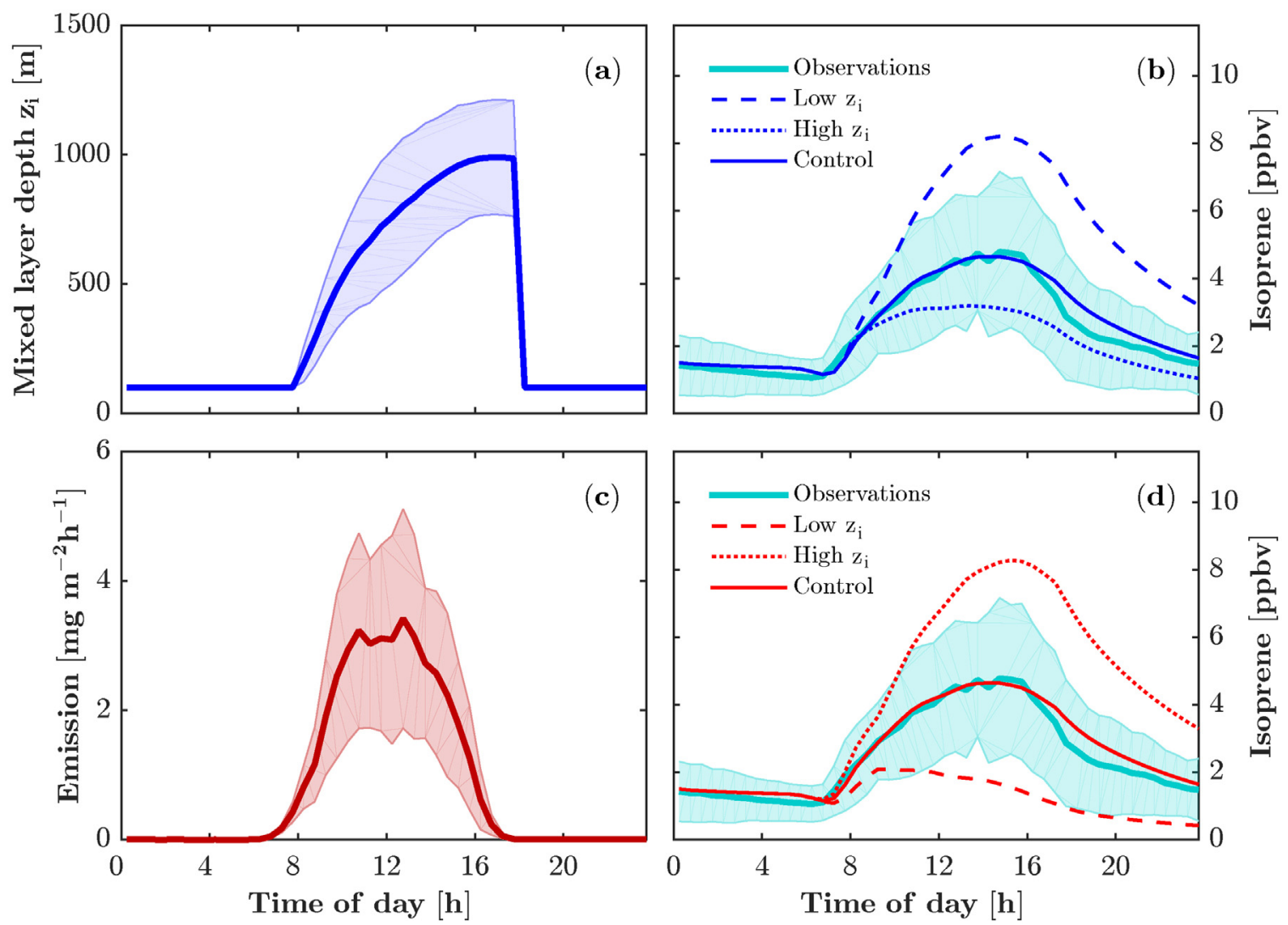

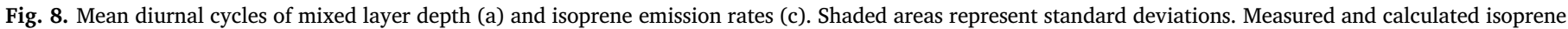
mixing ratios under different conditions of boundary layer depth (b) and emission rates (d). 

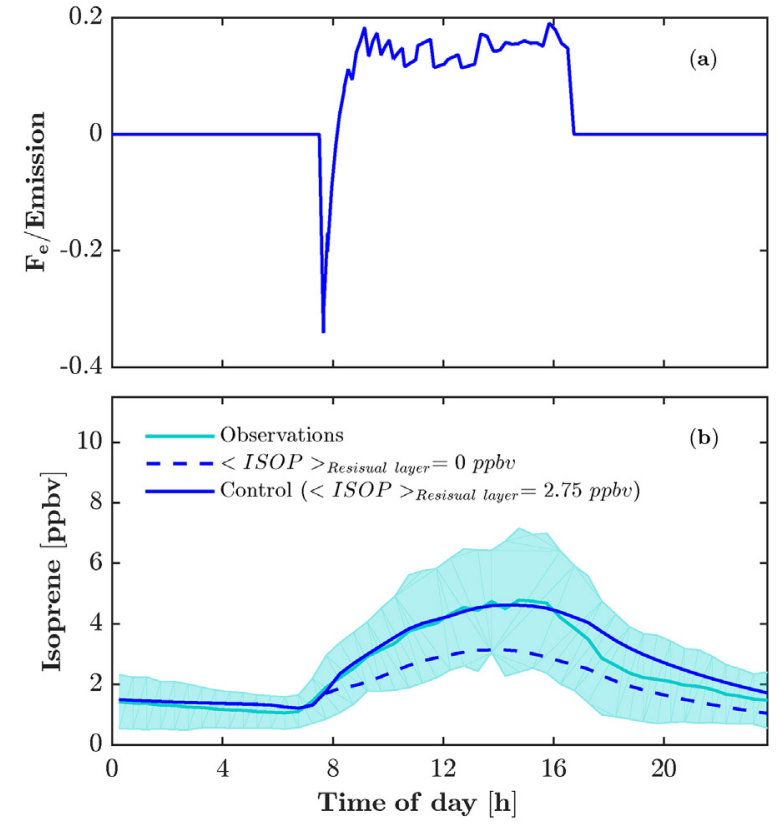

Fig. 9. Diurnal variations of the ratio of isoprene entrainment flux to emission (a). Measured and calculated isoprene mixing ratios under different conditions of isoprene content in the residual layer (b).

isoprene levels from averaged conditions.

Entrainment of air from the residual layer or the free atmosphere to the mixed layer can influence ambient isoprene levels in the air above the forest canopy. In this sensitivity analysis (Fig. 9), it was assumed that the isoprene mixing ratio $\left(\langle\mathrm{ISOP}\rangle_{R L}\right)$ observed around $17: 30 \mathrm{~h}$ (when the onset of the stable boundary layer occurred and a fraction of isoprene remained in the residual layer (Verver et al., 2000)) could be employed to estimate the entrainment using Eq. (8). The $\langle\mathrm{ISOP}\rangle_{R L}$ could be construed as the upper bound of the isoprene mixing ratio because chemical sinks were not considered during the nighttime. As the mixed layer developed in the early morning, the computed fraction of entrainment flux to isoprene emission attained maximum values amounting to $-34 \%$, indicating that entrainment enhanced the isoprene content of the mixed layer (Fig. 9a). After 9:00 h the ratios reached about $20 \%$, suggesting that entrainment contributed to the dilution of isoprene in the mixed layer (Fig. 9a). It is sometimes assumed that the free troposphere is devoid of isoprene (de Arellano et al., 2009). Therefore, additional simulations were performed to assess the impact of entraining isoprene-depleted air into the mixed layer. Results (Fig. 9b) showed that entrainment of isoprene-free air decreased the maximum isoprene mixing ratios by $32 \%$ while the controlled case $\left(\langle\mathrm{ISOP}\rangle_{F A}=2.75 \mathrm{ppbv}\right)$ consistently matched the observations. In summary, the sensitivity analysis (Fig. 9) demonstrated that the temporal patterns of ambient isoprene levels were strongly coupled to the entrainment process as confirmed by earlier studies (Karl et al., 2007; de Arellano et al., 2009).

Hydroxyl radicals exert control on the temporal patterns of isoprene above the rain forest. Recycling of $\mathrm{HO}$ from isoprene reactions (Taraborrelli et al., 2012; Fuchs et al., 2013) and segregation of isoprene-HO (Krol et al., 2000; Verver et al., 2000; Karl et al., 2007; Ouwersloot et al., 2011; Kaser et al., 2015) are investigated for their potential influence on ambient isoprene levels. Because the photochemical mechanism to study isoprene chemistry did not include HO recycling, several a priori $\chi$ values were included in the simulations. As expected, the recycling of $\mathrm{HO}$ enhanced the HO concentrations but in general reduced isoprene mixing ratios (Fig. 10a). Compared to the control simulations, the $\chi$ value of $100 \%$ contributed to $24 \%$ increase in $\mathrm{HO}$ concentrations and $16 \%$ underestimation of isoprene mixing ratios
(Fig. 10a). Simulated isoprene levels closely matched observations when the $\chi$ value of $20 \%$ was considered. As suggested in previous studies (Fuchs et al., 2013), the isomerization reactions associated with $\mathrm{HO}$ recycling need to be investigated as a function of NO concentrations. Slowing down the reaction rate of isoprene and HO (Reaction (13)) tended to increase both isoprene and HO (Fig. 10b). A 50\% reduction in the reaction rate caused the maxima of isoprene and HO to deviate from the control run by $16 \%$ and $42 \%$, respectively. Deviations in the inferred isoprene mixing ratios (Fig. 10) were lower than those associated with the physical processes described earlier (Section 3.3) and indicated that, within their likely ranges and as reported in other studies (Karl et al., 2007; Ouwersloot et al., 2011), isoprene-HO segregation played a lesser role in regulating ambient isoprene levels.

Isoprene reaction pathways and associated oxidant yields depend on the ambient NO levels. Several numerical model simulations were performed to examine the impacts of varying NO levels on isoprene and $\mathrm{HO}$ estimation. Initial levels and emissions of $\mathrm{NO}$ were prescribed in the zero-dimensional model to generate ambient NO levels that remained within the range of observations in the central Amazonia region (Torres and Buchan, 1988; Liu et al., 2016). Results (Fig. 11) indicated that as NO increased from 0.04 to $0.36 \mathrm{ppbv}$ then isoprene rapidly declined from its initial value of 4.0 to $0.2 \mathrm{pbbv}$ while at the same time $\mathrm{HO}$ exponentially increased from $1 \times 10^{6}$ to $13 \times 10^{6}$ radicals per $\mathrm{cm}^{3}$. Part of the explanation for the increases in $\mathrm{HO}$ concentrations is that the oxidation of isoprene produces hydroperoxyl radicals $\left(\mathrm{HO}_{2}\right)$ which react with $\mathrm{NO}$ to form $\mathrm{HO}$ and $\mathrm{NO}_{2}$ (Fuentes et al., 2000; Paulot et al., 2009a). Therefore, environments with elevated concentrations of NO can experience sufficient HO levels to promote the oxidation of biogenic hydrocarbons within the atmospheric boundary layer. Chemistry of isoprene in air with NO greater than $0.1 \mathrm{ppbv}$ is the salient process influencing the diel cycles of isoprene above the rain forest.

\subsection{Study limitations}

Because of the lack of crucial measurements such as foliage- and ecosystem-based isoprene emissions, several limitations are acknowledged with this study. The comparison of the leaf phenology between September and December cannot be made because these two months have similar LAI. Results from previous studies (Wu et al., 2016) were used to complement the statements about leaf age and the capacity to emit isoprene when comparing September and December. Also, the MODIS-derived LAI data have up to $20 \%$ uncertainties (Fensholt et al., 2004), which likely contributes to the variations in LAI estimated for August and December. The isoprene emission algorithm included multiple parameters to adjust for various climates and ecosystems. Without local foliage measurements, required parameters are challenging to adjust at the site level. The variability of foliage age as a function of canopy depth was not considered. In the tropics, it is likely that younger foliage can mostly remain in the forest crown. Isoprene and its reactants were assumed to stay well mixed within the ABL. Throughout the numerical model simulations, isoprene levels within the residual layer were kept constant with time. Daytime isoprene deposition velocity is calculated based on the reported cuticle resistances of ozone because of the lack of information for estimating the cuticle resistance for isoprene. Therefore, the deposition of isoprene remains a source of uncertainty. The assumed ABL thermodynamics and air chemistry applied to undisturbed conditions. Mesoscale convective systems frequently occur in the tropics and modify the thermodynamics of the lower atmosphere (e.g., $\gamma_{\theta_{V}}, \Delta \theta_{V}, z_{i}$ ), the spatio-temporal distribution of $\mathrm{O}_{3}$ and other reactive gases, and associated chemical cycles (Gerken et al., 2016). Taken together, these assumptions carry certain levels of uncertainties which can be addressed in future investigations.

\section{Conclusions}

Isoprene mixing ratios over the rain forest canopy exhibited 

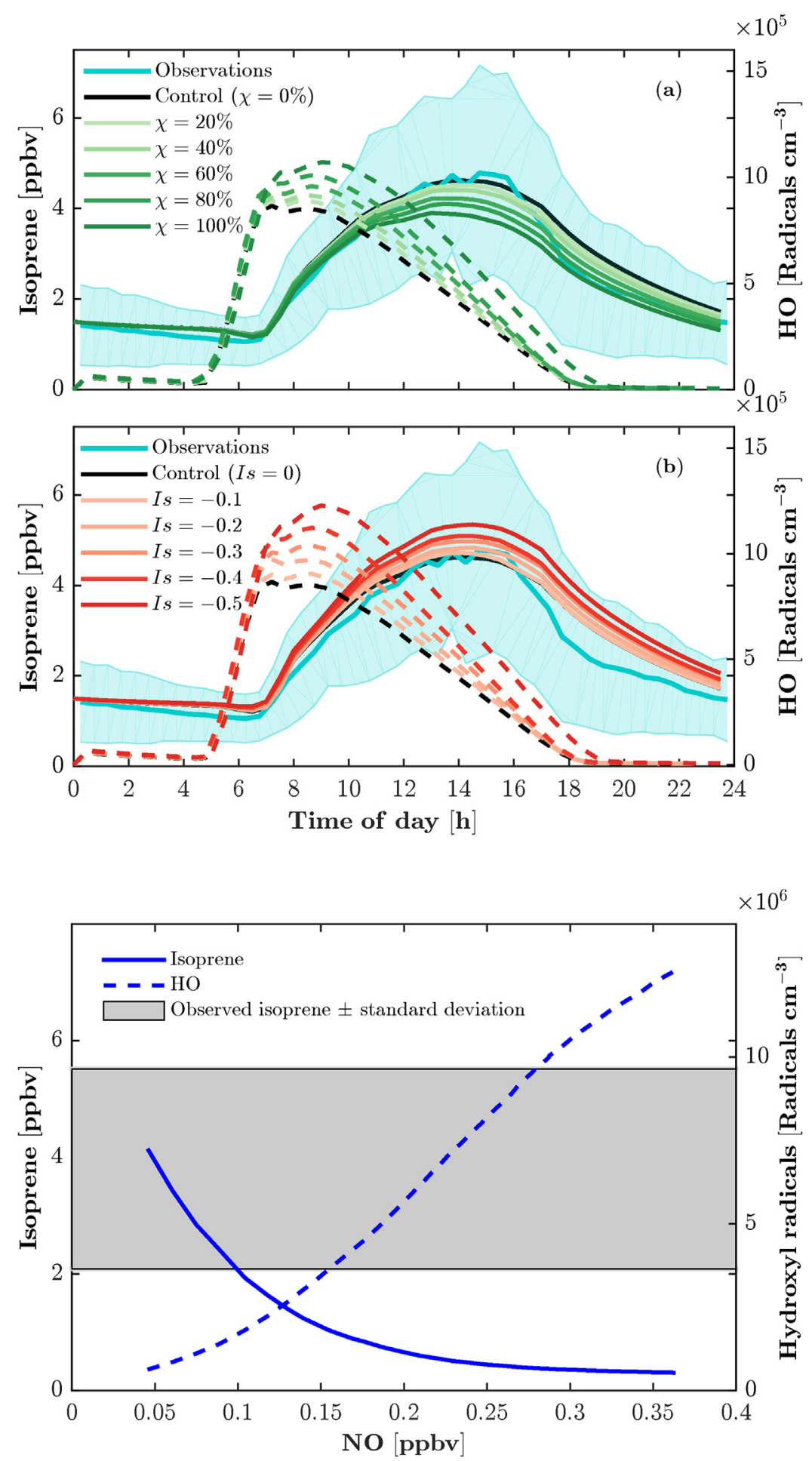

Fig. 10. Calculated isoprene mixing ratios under different conditions of hydroxyl radical (HO) recycling (a) and segregation of isoprene-HO (b). Solid lines (green, red and black) denote modeled isoprene mixing ratios and dashed lines represent modeled hydroxyl radicals. Cyan lines denote measured mean isoprene mixing ratios and shaded areas represent the standard deviations. (For interpretation of the references to color in this figure legend, the reader is referred to the web version of the article.)
Fig. 11. Variations of isoprene as a function of initial nitric oxide and hydroxyl radical. Photochemical model simulations included emissions of nitric oxide. Isoprene mixing ratio and hydroxyl radical concentration are daytime (10:00 to $14: 00 \mathrm{~h}$, local time) averages. Values of isoprene mixing ratios within the shaded area represent the averages of the standard deviation calculated during 10:00 to $14: 00 \mathrm{~h}$. substantial seasonality, with diurnal values in December reaching levels approximately $70 \%$ higher than those in June. Incoming photosynthetically active radiation and temperature, the two environmental variables modulating emissions, were almost identical in June and December but did not correspondingly explain the observed seasonality in isoprene levels. Instead, leaf phenology and quantity consistently followed the seasonality of isoprene. The dry months of August and September had the highest estimated isoprene emission rates, with averaged maximum flux densities of $11 \mathrm{mg} \mathrm{m}^{-2} \mathrm{~h}^{-1}$ prevailing due to the concomitant influences of high temperature $\left(>30^{\circ} \mathrm{C}\right)$ and incoming insolation, and high quality and quantity of foliage. New foliage, developed at the start of the wet season, had to accrue competency to emit isoprene. Therefore, aggregate foliage phenology and associated variations in putative basal emissions became important controls on isoprene seasonality. Not all seasonal variability in observed isoprene levels could be ascribed to changes in basal emissions. For instance, convective boundary layer depths, which exhibit clear seasonal cycles in the Amazon region, can also substantially influence ambient isoprene levels. Model results show that a $30 \%$ deeper boundary layer can lead to $31 \%$ reduction in estimated isoprene mixing ratios.

Several boundary layer processes influenced the diel cycles of isoprene and each processes contributed differently at different times of 
day. Dry deposition represented the main sink of isoprene during the nighttime. During the daytime, a significant amount of the emitted isoprene was chemically consumed via reactions involving $\mathrm{HO}$, with more than $50 \%$ of isoprene variability owing to oxidation.

Sensitivity analysis revealed that the air layer-averaged NO levels became the predominant factor promoting the isoprene oxidation through the reaction with HO. Several chemical pathways explain the NO-isoprene-HO relationship. The isoprene oxidation produces $\mathrm{HO}_{2}$ which combines with NO to form additional HO. Also, the rain forest emits large amounts of monoterpenes and sesquiterpenes whose reactions with $\mathrm{O}_{3}$ generate organic peroxyl radicals $\left(\mathrm{RO}_{2}\right)$. The $\mathrm{RO}_{2}$ subsequently reacts with $\mathrm{NO}$ to form $\mathrm{NO}_{2}$, which is a direct $\mathrm{O}_{3}$ precursor. In the presence of water vapor, the photolysis of $\mathrm{O}_{3}$ produces $\mathrm{HO}$. Therefore, the accurate determination of NO concentrations is crucially important for the reliable estimation of isoprene levels under low-NO and high-VOC conditions. Given that the Amazon rain forest frequently experiences enhanced levels of nitrogen oxides due to human activities such as biomass burning or urban polluted plumes, the atmospheric chemistry of isoprene can be greatly modified and thus impact its seasonal patterns.

\section{Acknowledgements}

The U.S. Department of Energy (DOE) supported the field studies as part of the GoAmazon 2014/5 project (grant SC0011075). Fundação de Amparo à Pesquisa do Estado de São Paulo (FAPESP) and Fundação de Amparo à Pesquisa do Estado do Amazonas (FAPEAM) funded the Brazilian component of the field studies. The Large-scale BiosphereAtmosphere Experiment in Amazonia (LBA) provided logistic support and made the flux tower and housing unit available to complete the field studies. Authors thank the support from the LBA central office that operated at INPA. The DOE Atmospheric Radiation Measurement (ARM) Climate Research Facility provided field logistic support. Authors thank Kolby Jardin for supplying gas mixture standards to calibrate the PTR-MS. JDF thanks Ana Maria Yáñez-Serrano for the field assistance with the calibration of the PTR-MS. JDF acknowledges support from the U.S. National Science Foundation (grant 1417914). Authors thank two anonymous reviewers who recommended revisions to improve the quality of the manuscript.

\section{Appendix A. Supplementary data}

Supplementary data associated with this article can be found, in the online version, at https://doi.org/10.1016/j.agrformet.2018.03.024.

\section{References}

Alves, E.G., Harley, P., Gonçalves, J.F.d.C., Moura, C.E.d.S., Jardine, K., 2014. Effects of light and temperature on isoprene emission at different leaf developmental stages of Eschweilera coriacea in central Amazon. Acta Amazon. 44 (1), 9-18.

Artaxo, P., Rizzo, L.V., Brito, J.F., Barbosa, H.M.J., Arana, A., Sena, E.T., Cirino, G.G., Bastos, W., Martin, S.T., Andreae, M.O., 2013. Atmospheric aerosols in Amazonia and land use change: from natural biogenic to biomass burning conditions. Faraday Discuss. 165, 203.

Atkinson, R., 1997. Gas-phase tropospheric chemistry of volatile organic compounds: 1. Alkanes and alkenes. J. Phys. Chem. Ref. Data 26 (2), 215-290.

Bakwin, P.S., Wofsy, S.C., Fan, S.-M., Keller, M., Trumbore, S.E., Da Costa, J.M., 1990. Emission of nitric oxide (NO) from tropical forest soils and exchange of NO between the forest canopy and atmospheric boundary layers. J. Geophys. Res. Atmos. 95 (D10), 16755-16764.

Barkley, M.P., Palmer, P.I., Kuhn, U., Kesselmeier, J., Chance, K., Kurosu, T.P., Martin, R.V., Helmig, D., Guenther, A., 2008. Net ecosystem fluxes of isoprene over tropical South America inferred from Global Ozone Monitoring Experiment (GOME) observations of HCHO columns. J. Geophys. Res. 113 (D20), D20304.

Brodkey, R.S., 1981. Fundamental of turbulent motion, mixing and kinetics. Chem. Eng. Commun. 8 (1-3), 1-23.

Bruno, R.D., Da Rocha, H.R., De Freitas, H.C., Goulden, M.L., Miller, S.D., 2006. Soil moisture dynamics in an eastern Amazonian tropical forest. Hydrol. Process. 20 (12), 2477-2489.

Butler, T.M., Taraborrelli, D., Brühl, C., Fischer, H., Harder, H., Martinez, M., Williams, J., Lawrence, M.G., Lelieveld, J., 2008. Improved simulation of isoprene oxidation chemistry with the ECHAM5/MESSy chemistry-climate model: lessons from the GABRIEL airborne field campaign. Atmos. Chem. Phys. 8 (16), 4529-4546.

Claeys, M., Graham, B., Vas, G., Wang, W., Vermeylen, R., Pashynska, V., Cafmeyer, J., Guyon, P., Andreae, M.O., Artaxo, P., Maenhaut, W., 2004. Formation of secondary organic aerosols through photooxidation of isoprene. Science 303 (5661), 1173-1176.

de Arellano, J.V.-G., van den Dries, K., Pino, D., 2009. On inferring isoprene emission surface flux from atmospheric boundary layer concentration measurements. Atmos. Chem. Phys. 9 (11), 3629-3640.

Doughty, D., Fuentes, J.D., Sakai, R., Hu, X.-M., Sanchez, K., 2015. Nocturnal isoprene declines in a semi-urban environment. J. Atmos. Chem. 72 (3-4), 215-234.

Fall, R., Monson, R.K., 1992. Isoprene emission rate and intercellular isoprene concentration as influenced by stomatal distribution and conductance. Plant Physiol. 100 (2), 987-992.

Fan, S.-M., Wofsy, S.C., Bakwin, P.S., Jacob, D.J., Fitzjarrald, D.R., 1990. Atmospherebiosphere exchange of $\mathrm{CO}_{2}$ and $\mathrm{O}_{3}$ in the central Amazon forest. J. Geophys. Res. 95 (D10), 16851-16864.

Fensholt, R., Sandholt, I., Rasmussen, M.S., 2004. Evaluation of MODIS LAI, fAPAR and the relation between FAPAR and NDVI in a semi-arid environment using in situ measurements. Remote Sens. Environ. 91 (3), 490-507.

Fisch, G., Tota, J., Machado, L.A.T., Dias, M.A.F.S., da, F., Lyra, R.F., Nobre, C.A., Dolman, A.J., Gash, J.H.C., 2004. The convective boundary layer over pasture and forest in Amazonia. Theor. Appl. Climatol. 78 (1-3), 47-59.

Freire, L., Gerken, T., Ruiz-Plancarte, J., Wei, D., Fuentes, J., Katul, G., Dias, N., Acevedo, O., Chamecki, M., 2017. Turbulent mixing and removal of ozone within an Amazon rainforest canopy. J. Geophys. Res. Atmos. 122, 2791-2811.

Fuchs, H., Hofzumahaus, A., Rohrer, F., Bohn, B., Brauers, T., Dorn, H., Häseler, R., Holland, F., Kaminski, M., Li, X., Lu, K., Nehr, S., Tillmann, R., Wegener, R., Wahner, A., 2013. Experimental evidence for efficient hydroxyl radical regeneration in isoprene oxidation. Nat. Geosci. 6 (12), 1023-1026.

Fuentes, J., Wang, D., Den Hartog, G., Neumann, H., Dann, T., Puckett, K., 1995. Modelled and field measurements of biogenic hydrocarbon emissions from a Canadian deciduous forest. Atmos. Environ. 29 (21), 3003-3017.

Fuentes, J.D., 1992. Effect of Foliage Surface Wetness on the Deposition of Ozone (Ph.D. thesis). University of Guelph, Ontario, Canada $145 \mathrm{pp}$.

Fuentes, J.D., Chamecki, M., dos Santos, R.M.N., Randow, C.V., Stoy, P.C., Katul, G., Fitzjarrald, D., Manzi, A., Gerken, T., Trowbridge, A., Freire, L.S., Ruiz-Plancarte, J., Maia, J.M.F., Tóta, J., Dias, N., Fisch, G., Schumacher, C., Acevedo, O., Mercer, J.R., Yañez-Serrano, A.M., 2016. Linking meteorology, turbulence, and air chemistry in the Amazon rain forest. Bull. Am. Meteorol. Soc. 97 (12), 2329-2342.

Fuentes, J.D., Gu, L., Lerdau, M., Atkinson, R., Baldocchi, D., Bottenheim, J.W., Ciccioli, P., Lamb, B., Geron, C., Guenther, A., Sharkey, T.D., Stockwell, W., 2000. Biogenic hydrocarbons in the atmospheric boundary layer: a review. Bull. Am. Meteorol. Soc. 81 (7), 1537-1575.

Fuentes, J.D., Wang, D., 1999. On the seasonality of isoprene emissions from a mixed temperate forest. Ecol. Appl. 9 (4), 1118-1131.

Fuentes, J.D., Wang, D., Gu, L., 1999. Seasonal variations in isoprene emissions from a boreal aspen forest. J. Appl. Meteorol. 38 (7), 855-869.

Gao, H., Fu, R., Dickinson, R.E., Juárez, R.I.N., 2008. A practical method for retrieving land surface temperature from AMSR-E over the Amazon forest. IEEE Trans. Geosci. Remote Sens. 46 (1), 193-199.

Gerken, T., Wei, D., Chase, R.J., Fuentes, J.D., Schumacher, C., Machado, L.A., Andreoli, R.V., Chamecki, M., de Souza, R.A.F., Freire, L.S., Jardine, A.B., Antonio, O.M., dos Santos, R.M.N., von Randow, C., dos Santos Costa, P., Stoy, P.C., Trowbridge, A.M., 2016. Downward transport of ozone rich air and implications for atmospheric chemistry in the Amazon rainforest. Atmos. Environ. 124, 64-76.

Goliff, W.S., Stockwell, W.R., Lawson, C.V., 2013. The regional atmospheric chemistry mechanism, version 2. Atmos. Environ. 68, 174-185.

Greenberg, J.P., Guenther, A.B., Petron, G., Wiedinmyer, C., Vega, O., Gatti, L.V., Tota, J., Fisch, G., 2004. Biogenic VOC emissions from forested Amazonian landscapes. Glob. Change Biol. 10 (5), 651-662.

Grinspoon, J., Bowman, W.D., Fall, R., 1991. Delayed onset of isoprene emission in developing velvet bean (Mucuna sp.) leaves. Plant Physiol. 97 (1), 170-174.

Guenther, A., Karl, T., Harley, P., Wiedinmyer, C., Palmer, P.I., Geron, C., 2006. Estimates of global terrestrial isoprene emissions using MEGAN (Model of Emissions of Gases and Aerosols from Nature). Atmos. Chem. Phys. 6 (11), 3181-3210.

Guenther, A.B., Jiang, X., Heald, C.L., Sakulyanontvittaya, T., Duhl, T., Emmons, L.K., Wang, X., 2012. The model of emissions of gases and aerosols from nature version 2.1 (MEGAN2.1): an extended and updated framework for modeling biogenic emissions. Geosci. Model Dev. 5 (6), 1471-1492.

Hu, X.-M., Fuentes, J.D., Toohey, D., Wang, D., 2015. Chemical processing within and above a loblolly pine forest in North Carolina, USA. J. Atmos. Chem. 72 (3-4), 235-259.

Hurst, J.M., Barket, D.J., Herrera-Gomez, O., Couch, T.L., Shepson, P.B., Faloona, I., Tan, D., Brune, W., Westberg, H., Lamb, B., Beisenthal, T., Young, V., Goldstein, A., Munger, J.W., Thornberry, T., Carroll, M.A., 2001. Investigation of the nighttime decay of isoprene. J. Geophys. Res. Atmos. 106 (D20), 24335-24346.

Jacob, D.J., Wofsy, S.C., 1988. Photochemistry of biogenic emissions over the Amazon forest. J. Geophys. Res. 93 (D2), 1477-1486.

Jardine, A.B., Jardine, K.J., Fuentes, J.D., Martin, S.T., Martins, G., Durgante, F., Carneiro, V., Higuchi, N., Manzi, A.O., Chambers, J.Q., 2015. Highly reactive lightdependent monoterpenes in the Amazon. Geophys. Res. Lett. 42 (5), 1576-1583.

Jardine, K.J., Jardine, A.B., Souza, V.F., Carneiro, V., Ceron, J.V., Gimenez, B.O., Soares, C.P., Durgante, F.M., Higuchi, N., Manzi, A.O., Goncalves, J.F., Garcia, S., Martin, S.T., Zorzanelli, R.F., Piva, L.R., Chambers, J.Q., 2016. Methanol and isoprene emissions from the fast growing tropical pioneer species Vismia guianensis (Aubl.) 
Pers. (Hypericaceae) in the central Amazon forest. Atmos. Chem. Phys. 16 (10), 6441-6452.

Jardine, K.J., Monson, R.K., Abrell, L., Saleska, S.R., Arneth, A., Jardine, A., Ishida, F.Y., Serrano, A.M.Y., Artaxo, P., Karl, T., Fares, S., Goldstein, A., Loreto, F., Huxman, T., 2012. Within-plant isoprene oxidation confirmed by direct emissions of oxidation products methyl vinyl ketone and methacrolein. Glob. Change Biol. 18 (3), 973-984.

Karl, T., Guenther, A., Yokelson, R.J., Greenberg, J., Potosnak, M., Blake, D.R., Artaxo, P., 2007. The tropical forest and fire emissions experiment: emission, chemistry, and transport of biogenic volatile organic compounds in the lower atmosphere over Amazonia. J. Geophys. Res. 112, D18302.

Karl, T., Potosnak, M., Guenther, A., Clark, D., Walker, J., Herrick, J.D., Geron, C., 2004. Exchange processes of volatile organic compounds above a tropical rain forest: implications for modeling tropospheric chemistry above dense vegetation. J. Geophys. Res. 109 (D18), D18306.

Kaser, L., Karl, T., Yuan, B., Mauldin, R.L., Cantrell, C.A., Guenther, A.B., Patton, E.G., Weinheimer, A.J., Knote, C., Orlando, J., Emmons, L., Apel, E., Hornbrook, R., Shertz, S., Ullmann, K., Hall, S., Graus, M., de Gouw, J., Zhou, X., Ye, C., 2015. Chemistryturbulence interactions and mesoscale variability influence the cleansing efficiency of the atmosphere. Geophys. Res. Lett. 42 (24) 10,894-10,903.

Kesselmeier, J., 2002. Concentrations and species composition of atmospheric volatile organic compounds (VOCs) as observed during the wet and dry season in rondônia (Amazonia). J. Geophy. Res. 107 (D20), 8053.

Kim, S.-W., Barth, M., Trainer, M., 2016. Impact of turbulent mixing on isoprene chemistry. Geophys. Res. Lett. 43 (14), 7701-7708.

Krol, M.C., Molemaker, M.J., de Arellano, J.V.G., 2000. Effects of turbulence and heterogeneous emissions on photochemically active species in the convective boundary layer. J. Geophys. Res. Atmos. 105 (D5), 6871-6884.

Kuhn, U., Rottenberger, S., Biesenthal, T., Wolf, A., Schebeske, G., Ciccioli, P., Brancaleoni, E., Frattoni, M., Tavares, T.M., Kesselmeier, J., 2004. Seasonal differences in isoprene and light-dependent monoterpene emission by Amazonian tree specie. Global Change Biol. 10 (5), 663-682.

Kuhn, U., Andreae, M.O., Ammann, C., Araújo, A.C., Brancaleoni, E., Ciccioli, P., Dindorf, T., Frattoni, M., Gatti, L.V., Ganzeveld, L., Kruijt, B., Lelieveld, J., Lloyd, J., Meixner, F.X., Nobre, A.D., Pöschl, U., Spirig, C., Stefani, P., Thielmann, A., Valentini, R., Kesselmeier, J., 2007. Isoprene and monoterpene fluxes from central Amazonian rainforest inferred from tower-based and airborne measurements, and implications on the atmospheric chemistry and the local carbon budget. Atmos. Chem. Phys. 7 (11), 2855-2879.

Lelieveld, J., Butler, T.M., Crowley, J.N., Dillon, T.J., Fischer, H., Ganzeveld, L., Harder, H., Lawrence, M.G., Martinez, M., Taraborrelli, D., Williams, J., 2008. Atmospheric oxidation capacity sustained by a tropical forest. Nature 452 (7188), 737-740.

Levis, S., Wiedinmyer, C., Bonan, G.B., Guenther, A., 2003. Simulating biogenic volatile organic compound emissions in the community climate system model. J. Geophys. Res.: Atmos. 108 (D21), 4659.

Liu, Y., Brito, J., Dorris, M.R., Rivera-Rios, J.C., Seco, R., Bates, K.H., Artaxo, P., Duvoisin, S., Keutsch, F.N., Kim, S., Goldstein, A.H., Guenther, A.B., Manzi, A.O., Souza, R.A.F., Springston, S.R., Watson, T.B., McKinney, K.A., Martin, S.T., 2016. Isoprene photochemistry over the Amazon rainforest. Proc. Natl. Acad. Sci. U. S. A. 113 (22), 6125-6130.

Loreto, F., Velikova, V., 2001. Isoprene produced by leaves protects the photosynthetic apparatus against ozone damage, quenches ozone products, and reduces lipid peroxidation of cellular membranes. Plant Physiol. 127 (4), 1781-1787.

Luizao, F.J., 1995. Ecological Studies in Contrasting Forest Types in Central Amazonia (Ph.D. thesis). University of Stirling, Stirling, UK 288 pp.

Madronich, S., Flocke, S., 1999. The role of solar radiation in atmospheric chemistry. The Handbook of Environmental Chemistry. Springer Berlin Heidelberg, pp. 1-26.

Malhi, Y., 2002. Energy and water dynamics of a central Amazonian rain forest. J. Geophys. Res. 107 (D20 8061), 1-45.

Marques Filho, A.d.O., Dallarosa, R.G., Pachêco, V.B., 2005. Radiação solar e distribuição vertical de área foliar em floresta-Reserva Biológica do Cuieiras-ZF2, Manaus. Acta Amazôn. 35 (4), 427-436.

Martin, S.T., Artaxo, P., Machado, L., Manzi, A., Souza, R., Schumacher, C., Wang, J., Andreae, M., Barbosa, H., Fan, J., Fisch, G., Goldstein, A.H., Guenther, A., Jimenez, J.L., Pø‘schl, U., Dias, M.A., Smith, J.N., Wendisch, M., 2016. Introduction: observations and modeling of the Green Ocean Amazon (GoAmazon2014/5). Atmos. Chem. Phys. 16 (8), 4785-4797.

McWilliam, A.-L.C., Roberts, J.M., Cabral, O.M.R., Leitao, M.V.B.R., de Costa, A.C.L., Maitelli, G.T., Zamparoni, C.A.G.P., 1993 jun. Leaf area index and above-ground biomass of terra firme rain forest and adjacent clearings in Amazonia. Funct. Ecol. 7 (3), 310-317.

Monson, R., Harley, P., Litvak, M., Wildermuth, M., Guenther, A., Zimmerman, P., Fall, R., 1994. Environmental and developmental controls over the seasonal pattern of isoprene emission from aspen leaves. Oecologia 99 (3-4), 260-270.

Monson, R.K., Fall, R., 1989. Isoprene emission from aspen leaves: influence of environment and relation to photosynthesis and photorespiration. Plant Physiol. 90 (1), 267-274.

Myneni, R.B., Yang, W., Nemani, R.R., Huete, A.R., Dickinson, R.E., Knyazikhin, Y., Didan, K., Fu, R., Juárez, R.I.N., Saatchi, S.S., Hashimoto, H., Ichii, K., Shabanov, N.V., Tan, B., Ratana, P., Privette, J.L., Morisette, J.T., Vermote, E.F., Roy, D.P., Wolfe, R.E., Running, S.W., Votava, P., El-Saleous, N., Devadiga, S., Su, Y., Salomonson, V.V., 2007. Large seasonal swings in leaf area of Amazon rainforests. Proc. Natl. Acad. Sci. U. S. A. 104 (12), 4820-4823.

Nappo, C.J., van Dop, H., 1994. Simple boundary layer description for global dispersion models. J. Geophys. Res. 99 (D5), 10527-10534.

Nepstad, D.C., de Carvalho, C.R., Davidson, E.A., Jipp, P.H., Lefebvre, P.A., Negreiros, G.H., da Silva, E.D., Stone, T.A., Trumbore, S.E., Vieira, S., 1994. The role of deep roots in the hydrological and carbon cycles of Amazonian forests and pastures. Nature 372 (6507), 666.

Nguyen, T.B., Crounse, J.D., Teng, A.P., Clair, J.M.S., Paulot, F., Wolfe, G.M., Wennberg, P.O., 2015. Rapid deposition of oxidized biogenic compounds to a temperate forest. Proc. Natl. Acad. Sci. U. S. A. 112 (5), E392-E401.

Nölscher, A.C., Yañez-Serrano, A.M., Wolff, S., de Araujo, A.C., Lavrič, J.V., Kesselmeier, J., Williams, J., 2016. Unexpected seasonality in quantity and composition of Amazon rainforest air reactivity. Nat. Commun. 7, 10383.

Ouwersloot, H.G., de Arellano, J.V.-G., van Heerwaarden, C.C., Ganzeveld, L.N., Krol, M.C., Lelieveld, J., 2011. On the segregation of chemical species in a clear boundary layer over heterogeneous land surfaces. Atmos. Chem. Phys. 11 (20), 10681-10704.

Palmer, P.I., Abbot, D.S., Fu, T.-M., Jacob, D.J., Chance, K., Kurosu, T.P., Guenther, A., Wiedinmyer, C., Stanton, J.C., Pilling, M.J., Pressley, S.N., Lamb, B., Sumner, A.L., 2006. Quantifying the seasonal and interannual variability of North American isoprene emissions using satellite observations of the formaldehyde column. J. Geophys. Res. 111 (D12).

Palmer, P.I., Barkley, M.P., Kurosu, T.P., Lewis, A.C., Saxton, J.E., Chance, K., Gatti, L.V., 2007. Interpreting satellite column observations of formaldehyde over tropical South America. Philos. Trans. R. Soc. A: Math. Phys. Eng. Sci. 365 (1856), 1741-1751.

Paulot, F., Crounse, J., Kjaergaard, H., Kroll, J., Seinfeld, J., Wennberg, P., 2009a. Isoprene photooxidation: new insights into the production of acids and organic nitrates. Atmos. Chem. Phys. 9 (4), 1479-1501.

Paulot, F., Crounse, J.D., Kjaergaard, H.G., Kurten, A., Clair, J.M.S., Seinfeld, J.H., Wennberg, P.O., 2009b. Unexpected epoxide formation in the gas-phase photooxidation of isoprene. Science 325 (5941), 730-733.

Paulson, S.E., Orlando, J.J., 1996. The reactions of ozone with alkenes: an important source of HOx in the boundary layer. Geophys. Res. Lett. 23 (25), 3727-3730.

Pöschl, U., Martin, S., Sinha, B., Chen, Q., Gunthe, S., Huffman, J., Borrmann, S., Farmer, D., Garland, R., Helas, G., Jimenez, J., King, S., Manzi, A., Mikhailov, E., Pauliquevis, T., Petters, M., Prenni, A., Roldin, P., Rose, D., Schneider, J., Su, H., Zorn, S., Artaxo, P., Andreae, M., 2010. Rainforest aerosols as biogenic nuclei of clouds and precipitation in the Amazon. Science 329 (5998), 1513-1516.

Rinne, H., Guenther, A., Greenberg, J., Harley, P., 2002. Isoprene and monoterpene fluxes measured above Amazonian rainforest and their dependence on light and temperature. Atmos. Environ. 36 (14), 2421-2426.

Rizzo, L.V., Artaxo, P., Karl, T., Guenther, A., Greenberg, J., 2010. Aerosol properties, incanopy gradients, turbulent fluxes and VOC concentrations at a pristine forest site in Amazonia. Atmos. Environ. 44 (4), 503-511.

Rummel, U., Ammann, C., Kirkman, G., Moura, M., Foken, T., Andreae, M., Meixner, F., 2007. Seasonal variation of ozone deposition to a tropical rain forest in southwest Amazonia. Atmos. Chem. Phys. 7 (20), 5415-5435.

Sander, S.P., Friedl, R., Golden, D., Kurylo, M., Moortgat, G., Wine, P., Ravishankara, A., Kolb, C., Molina, M., Finlayson-Pitts, B., Huie, R.E., Orkin, V.L., 2006. Chemical Kinetics and Photochemical Data for Use in Atmospheric Studies Evaluation Number 15. Tech. Rep. Jet Propulsion Laboratory, California Institute of Technology, Pasadena, CA.

Santos, D.M., Acevedo, O.C., Chamecki, M., Fuentes, J.D., Gerken, T., Stoy, P.C., 2016. Temporal scales of the nocturnal flow within and above a forest canopy in Amazonia. Bound. Layer Meteorol. 161 (1), 73-98.

Seefeld, S., Stockwell, W.R., 1999. First-order sensitivity analysis of models with timedependent parameters: an application to PAN and ozone. Atmos. Environ. 33 (18), 2941-2953.

Sharkey, T., Loreto, F., Delwiche, C., 1991. High carbon dioxide and sun/shade effects on isoprene emission from oak and aspen tree leaves. Plant Cell Environ. 14 (3), 333-338.

Sharkey, T.D., Wiberley, A.E., Donohue, A.R., 2008. Isoprene emission from plants: why and how. Ann. Bot. 101 (1), 5-18.

Sharkey, T.D., Yeh, S., 2001. Isoprene emission from plants. Annu. Rev. Plant Physiol. Plant Mol. Biol. 52 (1), 407-436.

Sigler, J.M., Fuentes, J.D., Heitz, R.C., Garstang, M., Fisch, G., 2002. Ozone dynamics and deposition processes at a deforested site in the Amazon basin. AMBIO 31 (1), 21-27.

Singsaas, E.L., Laporte, M.M., Shi, J.-Z., Monson, R.K., Bowling, D. R., Johnson, K., Lerdau, M., Jasentuliytana, A., Sharkey, T.D., 1999. Kinetics of leaf temperature fluctuation affect isoprene emission from red oak (Quercus rubra) leaves. Tree Physiol. 19 (14), 917-924.

Sombroek, W., 2001. Spatial and temporal patterns of Amazon rainfall. AMBIO 30 (7), 388-396.

Stone, D., Whalley, L.K., Heard, D.E., 2012. Tropospheric $\mathrm{OH}$ and $\mathrm{HO}_{2}$ radicals: field measurements and model comparisons. Chem. Soc. Rev 41 (19), 6348-6404.

Strong, C., Fuentes, J., Garstang, M., Betts, A., 2005. Daytime cycle of low-level clouds and the tropical convective boundary layer in southwestern Amazonia. J. Appl. Meteorol. 44 (10), 1607-1619.

Stull, R.B., 1988. An Introduction to Boundary Layer Meteorology. Kluwer Academic Publisher, Dordrecht 666 pp.

Surratt, J.D., Chan, A.W.H., Eddingsaas, N.C., Chan, M., Loza, C.L., Kwan, A.J., Hersey, S.P., Flagan, R.C., Wennberg, P.O., Seinfeld, J.H., 2009. Reactive intermediates revealed in secondary organic aerosol formation from isoprene. Proc. Natl. Acad. Sci. U. S. A. 107 (15), 6640-6645.

Taraborrelli, D., Lawrence, M., Crowley, J., Dillon, T., Gromov, S., Groß, C., Vereecken, L., Lelieveld, J., 2012. Hydroxyl radical buffered by isoprene oxidation over tropical forests. Nat. Geosci. 5 (3), 190-193.

Torres, A.L., Buchan, H., 1988. Tropospheric nitric oxide measurements over the Amazon basin. J. Geophys. Res. 93 (D2), 1396-1406.

Tóta, J., Fitzjarrald, D.R., da Silva Dias, M.A.F., 2012. Amazon rainforest exchange of carbon and subcanopy air flow: Manaus LBA site - a complex terrain condition. Sci. World J. 2012, 1-19. 
Verver, G.H.L., van Dop, H., Holtslag, A.A.M., 2000. Turbulent mixing and the chemical breakdown of isoprene in the atmospheric boundary layer. J. Geophys. Res. Atmos. 105 (D3), 3983-4002.

Wesely, M., Hicks, B., 2000. A review of the current status of knowledge on dry deposition. Atmos. Environ. 34 (12), 2261-2282.

Wesely, M.L., Doskey, P.V., Shannon, J., 2002. Deposition Parameterizations for the Industrial Source Complex (ISC3) Model. Tech. Rep. Argonne National Laboratory, Argonne, IL.

Whalley, L., Edwards, P., Furneaux, K., Goddard, A., Ingham, T., Evans, M., Stone, D. Hopkins, J., Jones, C.E., Karunaharan, A., Lee, J., Lewis, A., Monks, P., Moller, S. Heard, D., 2011. Quantifying the magnitude of a missing hydroxyl radical source in a tropical rainforest. Atmos. Chem. Phys. 11 (14), 7223-7233.

Wilkinson, M.J., Monson, R.K., Trahan, N., Lee, S., Brown, E., Jackson, R.B., Polley, H.W., Fay, P.A., Fall, R., 2009. Leaf isoprene emission rate as a function of atmospheric $\mathrm{CO}_{2}$ concentration. Glob. Change Biol. 15 (5), 1189-1200.

Wu, J., Albert, L.P., Lopes, A.P., Restrepo-Coupe, N., Hayek, M., Wiedemann, K.T., Guan,
K., Stark, S.C., Christoffersen, B., Prohaska, N., Tavares, J.V., Marostica, S., Kobayashi, H., Ferreira, M.L., Campos, K.S., da Silva, R., Brando, P.M., Dye, D.G., Huxman, T.E., Huete, A.R., Nelson, B.W., Saleska, S.R., 2016. Leaf development and demography explain photosynthetic seasonality in Amazon evergreen forests. Science 351 (6276), 972-976.

Yang, W., Tan, B., Huang, D., Rautiainen, M., Shabanov, N.V., Wang, Y., Privette, J.L. Huemmrich, K.F., Fensholt, R., Sandholt, I., Weiss, M., Ahl, D.E., Gower, S.T., Nemani, R.R., Knyazikhin, Y., Myneni, R.B., 2006. Modis leaf area index products: from validation to algorithm improvement. IEEE Trans. Geosci. Remote Sens. 44 (7), 1885-1898.

Zhang, L., Brook, J.R., Vet, R., 2003. A revised parameterization for gaseous dry deposition in air-quality models. Atmos. Chem. Phys. 3 (6), 2067-2082.

Zhang, Q., Manzoni, S., Katul, G., Porporato, A., Yang, D., 2014. The hysteretic evapotranspiration-vapor pressure deficit relation. J. Geophys. Res. Biogeosci. 119 (2), 125-140. 